The Free Internet Journal

for Organic Chemistry
Review

Arkivoc 2018, part i, 0-0

\title{
Synthesis and applications of bi- and bis-triazole systems
}

\author{
Kamal M. Dawood, ${ }^{* a}$ Bakr F. Abdel-Wahab, ${ }^{b}$ and Mohamed A. Raslanc \\ ${ }^{a}$ Chemistry Department, Faculty of Science, Cairo University, Giza 12613, Egypt \\ ${ }^{b}$ Applied Organic Chemistry Department, National Research Centre, Dokki, Giza, Egypt \\ ${ }^{c}$ Department of Chemistry, Faculty of Science, Aswan University, 81528 Aswan, Egypt \\ E-mail: dr dawood@yahoo.com
}

Received 02-09-2018

Accepted 03-27-2018

Published on line $04-24-2018$

\section{Abstract}

The current review article represents the synthetic routes to all possible classes of bi- and bis-triazole systems along with their research and biological applications. The classification is based on the connection between the two triazole rings.

bi-triazoles:<smiles>N=CC1=[In]C=N1</smiles>
$\mathrm{HN}-\mathrm{N} \quad \mathrm{N}-\mathrm{N} H$<smiles>[V]=c1cccc[nH]1</smiles>

$\mathrm{N}-\mathrm{N} \quad \mathrm{N}-\mathrm{N}$<smiles>c1nnc(-c2cn[nH]n2)[nH]1</smiles>

bis-triazoles:<smiles>c1cc(-c2cn[nH]n2)n[nH]1</smiles><smiles>c1nnc(CCc2nnc[nH]2)[nH]1</smiles>

Keywords: Bi-triazoles, bis-triazoles, synthesis, applications, heterocycles 


\section{Table of Contents}

1. Introduction

2. Synthesis and Applications of Bi-triazole Systems

2.1. 1,1'-Bi-triazoles

2.2. 1,3'-Bi-triazoles

2.3. 1,5`-Bi-triazoles

2.4. 3,3'-Bi-triazoles

2.5. 3,4'-Bi-triazoles

2.6. 4,4'-Bi-triazoles

2.7. 4,5`-Bi-triazoles

2.8. 5,5`-Bi-triazoles

3. Synthesis and Applications of Bis-triazole Systems

3.1. Bis-(1,2,3-triazoles)

3.2. Bis-(1,2,4-triazoles)

4. References

\section{Introduction}

1,2,3- and 1,2,4-Triazoles are important heterocyclic scaffolds of interesting chemical and biological applications. Several therapeutically active compounds containing 1,2,3-triazole moiety have been reported as antimicrobials, anti-HIV agents and kinase inhibitors. ${ }^{1-4}$ Some $1,2,4$-triazole derivatives have antibacterial ${ }^{5-7}$ and antifungal ${ }^{8,9}$ properties. Triazole units were incorporated in the core structure of some commercial drugs in the market. For example, Cefatrizine is using as antibiotic, Tazobactum as anti-bacterial agent ${ }^{10,11}$ and Suvorexant for the treatment of insomnia, was approved by the US-FDA ${ }^{12}$ in 2014 (Figure 1). 1,2,3- and 1,2,4triazoles were also employed as efficient corrosion inhibitors in an acid aqueous medium. ${ }^{13,14}$ Considerable interest is also focused on the synthesis of bi-heterocycles, due to their wide range of applications. For example, 3,3`-bi-1,2,4-triazoles have proved to possess bactericidal, fungicidal, and anthelmintic activities. ${ }^{15}$ Some bis-triazole-based commercial drugs are also available in the market, for example Fluconazole, Itraconazole and Posaconazole were used as antifungal drugs and Vorozole as antineoplastic drug (Figure 1).

Fluconazole was the first-line bis-triazole-antifungal drug recommended by World Health Organization (WHO). ${ }^{16-19}$ Nonsymmetric 1,3`-Bitriazole derivatives were reported to have antiviral activity against tobacco mosaic virus and exhibited powerful antiproliferative effects on different cancer cell lines. ${ }^{20}$ The application of bitriazoles as chelating $\mathrm{N}$-heterocyclic carbene ligands for ruthenium(II), palladium(II), and rhodium and their applications in catalytic organic synthesis have also been reported. ${ }^{21,22}$ The coordination chemistry of the $\pi$ electron excessive bi-1,2,4-triazole ligands was also intensively explored for synthesis of coordination polymers with unique properties. ${ }^{23-27}$ In the view of the above results and in connection with our previous review articles about biologically active heterocyclic systems, ${ }^{28-33}$ we prepared this review to disclose the intensive survey on the synthetic routes to symmetrical and nonsymmetrical bi- and bis- triazole systems (Figure 2) and their applications reported in the literature until the end of 2017. 
<smiles>NC(C(=O)NC1C(=O)N2C(C(=O)O)=C(CCc3c[nH]nn3)CS[C@H]12)c1ccc(O)cc1</smiles><smiles>Cn1nnc2ccc(C(c3ccc(Cl)cc3)n3cncn3)cc21</smiles>

Vorozole<smiles>OC(Cn1cncn1)(Cn1cncn1)c1ccc(F)cc1F</smiles>

Fluconazole<smiles>Cc1ccc(-n2nccn2)c(C(=O)N2CCN(c3nc4cc(Cl)ccc4o3)CC[C@H]2C)c1</smiles><smiles></smiles>

$$
\begin{array}{ll}
\mathrm{R}=\mathrm{CH}(\mathrm{Me}) \mathrm{CH}_{2} \mathrm{CH}_{3} & \text { Itraconazole } \\
\mathrm{R}=\mathrm{CH}(\mathrm{Et}) \mathrm{CH}(\mathrm{OH}) \mathrm{CH}_{3} & \text { Posaconazole }
\end{array}
$$

Figure 1. Triazole-based commercial drugs.<smiles>c1n[nH]nc1-c1cn[nH]n1</smiles>

bi-1,2,3-triazoles<smiles>c1nnc(-c2nnc[nH]2)[nH]1</smiles>

bi-1,2,4-triazoles<smiles>c1nnc(-c2cn[nH]n2)[nH]1</smiles>

(1,2,3-triazolyl)-1,2,4-triazoles

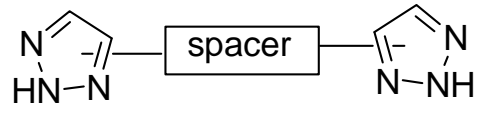

bis-1,2,3-triazoles<smiles>ClC1C2CC3CC(C3c3nnc[nH]3)C12</smiles>

bis-1,2,4-triazoles

Figure 2. Structures of bi- and bis- triazole systems.

\section{Synthesis and Application of Bitriazole Systems}

\subsection{1,1'-Bi-triazoles}

Treatment of 3,4-phthaloylisatoic anhydride 1 with oxamide-dihydrazone 2 in nitrobenzene and pyridine at $150{ }^{\circ} \mathrm{C}$, followed by treatment with polyphosphoric acid at $130{ }^{\circ} \mathrm{C}$, then $175^{\circ} \mathrm{C}$ afforded the $5,5^{\prime}$-bis $(1$-amino-2anthraquinonyl)-1,1'-bi-1,2,3-triazole derivative 3 (Scheme 1 ). ${ }^{34}$ 


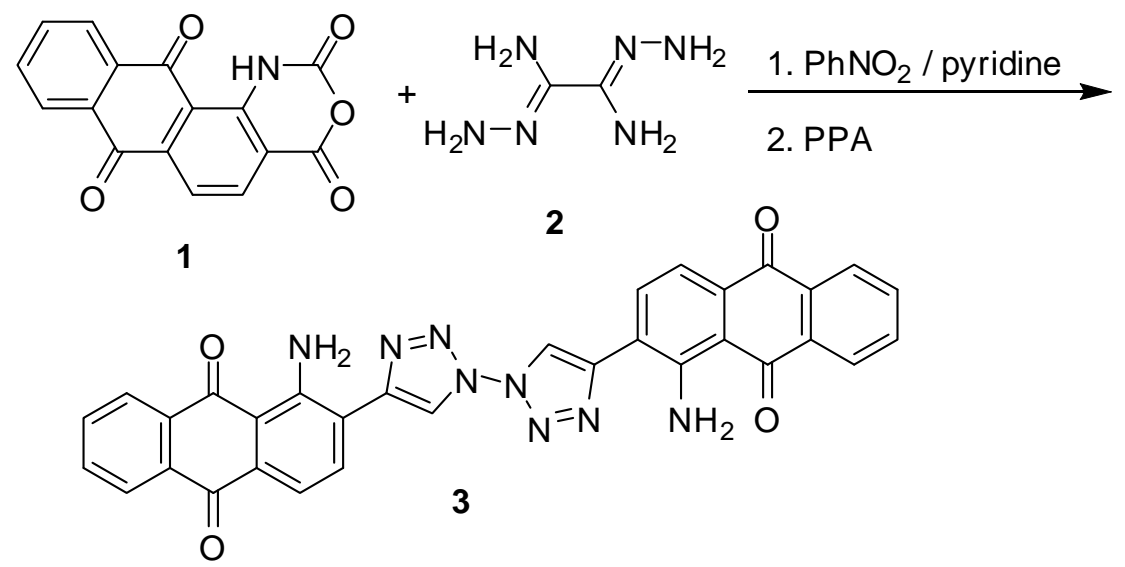

\section{Scheme 1}

\subsection{1,3'-Bi-triazoles}

The 1,3'-bitriazole compounds 6 were synthesized in good to excellent yields via the copper(I)-catalyzed Huisgen reaction of the azidotriazole 4 with alkynes 5 . Treatment of 6 with $\mathrm{NH}_{3} / \mathrm{MeOH}$ at room temperature resulted in the formation of the 1,3'-bitriazole derivatives 7 (Scheme 2). ${ }^{35,36}$ The bitriazole compounds 6 showed high antiviral activity against tobacco mosaic virus.

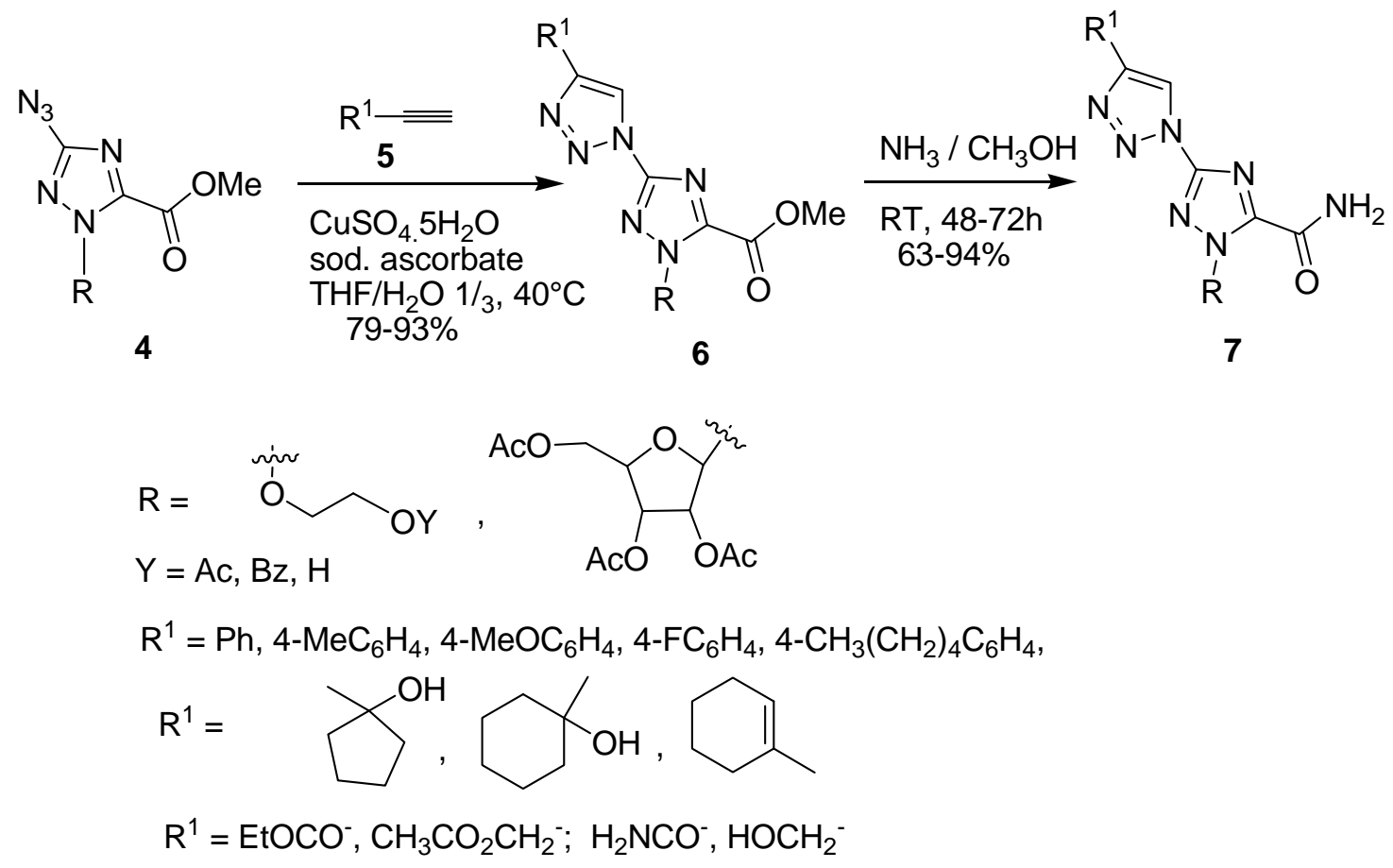

\section{Scheme 2}

The 1,3`-bi-triazoles $\mathbf{1 0}$ and $\mathbf{1 2}$ were prepared by a nucleophilic substitution reaction of the sodium salt of 1,2,4-triazole 8 with the halotriazole derivatives 9 and 11, respectively (Scheme 3). ${ }^{37}$ 


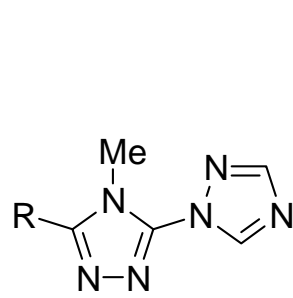

$1275 \%$

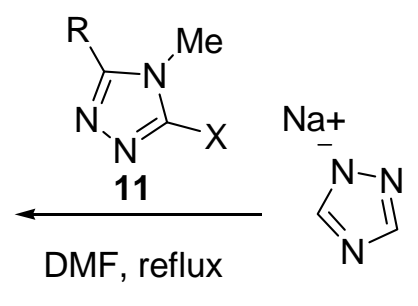

8

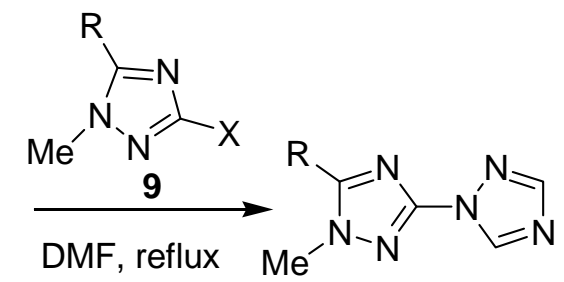

$10 \quad 55-60 \%$

$$
\mathrm{R}=\mathrm{H}, \mathrm{Me} \quad \mathrm{X}=\mathrm{Cl} \text { or } \mathrm{Br}
$$

\section{Scheme 3}

\subsection{1,5'-Bi-triazoles}

Treatment the sodium salt of 1,2,4-triazole 8 with the halotriazole derivatives 9 yielded the 1,5`-bitriazole 13 in high yield (Scheme 4). ${ }^{37}$

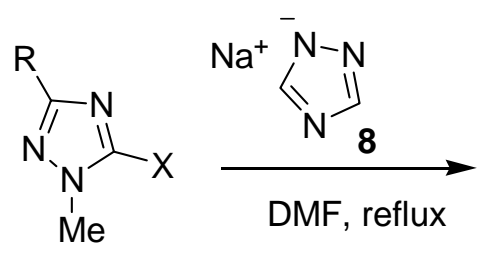

9

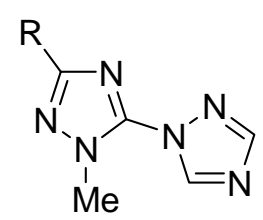

$1380 \%$

$$
\mathrm{R}=\mathrm{H}, \mathrm{Me} \quad \mathrm{X}=\mathrm{Cl}, \mathrm{Br}
$$

\section{Scheme 4}

The nucleophilic aromatic substitution reaction of 1,3-dinitro-1,2,4-triazole 14 with sodium salt of 3-nitro1,2,4-triazoles 15 in methanol and sodium carbonate at room temperature furnished the 1,5'-bi-1,2,4-triazole derivatives 16 (Scheme 5). ${ }^{38}$ The bi-triazoles 16 exhibited various energetic properties with high thermal stability and low sensitivity.<smiles>O=[N+]([O-])c1ncn([N+](=O)[O-])n1</smiles>

14<smiles>[R]c1nc([N+](=O)[O-])n[nH]1</smiles>

15<smiles>COC(=O)C(C)OC(=O)O[Na]</smiles>

16

$$
\mathrm{R}=\mathrm{H}, \mathrm{NH}_{2}
$$

\section{Scheme 5}

The synthesis of the $1,5^{`}$-bitriazole derivatives 18 was conducted under mild conditions, where the azidotriazole derivative $\mathbf{1 7}$ was readily engaged in a copper(I)-catalyzed Huisgen reaction with various terminal acetylenes 5. Treatment the bi-triazolyl compounds 18 with $\mathrm{NH}_{3} / \mathrm{MeOH}$ led to the formation of the corresponding amides 19 (Scheme 6). ${ }^{39,40}$ The 1,5'-bitriazole derivatives 18 and 19 constituted interesting leads for the development of new antiviral candidates where they were more potent antiviral than the commercial products, DHT and ribavirin. 


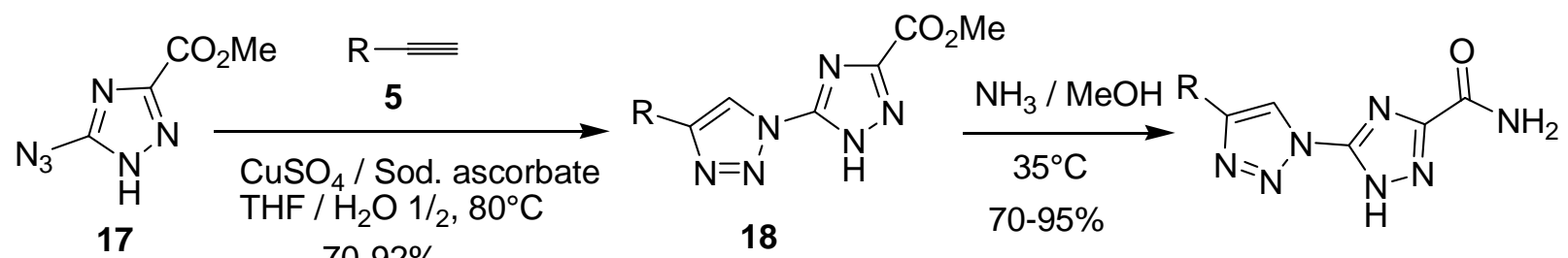

17

$70-92 \%$

18

19

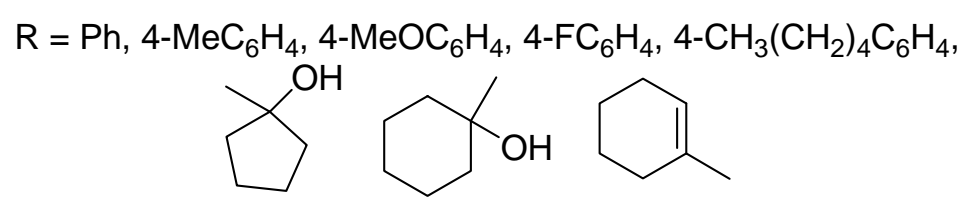

\section{Scheme 6}

1,5-Bi-1,2,4-triazoles 21 were obtained in 20-70\% yields by the reaction of 1-nitro-1,2,4-triazoles 20 with aqueous alkali hydroxides and reducing agents $\left(\mathrm{KI}, \mathrm{Fe}^{2+}, \mathrm{H}_{2} \mathrm{PO}_{2}^{-}\right)$or with triethylamine in acetonitrile (Scheme 7). ${ }^{41}$

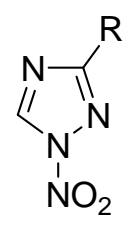

20<smiles>[R]c1n[nH]c(-n2cnc([R])n2)n1</smiles>

21

$\mathrm{R}=\mathrm{Cl}, \mathrm{Br}, \mathrm{NO}_{2}$

\section{Scheme 7}

\subsection{3,3'-Bi-triazoles}

Reaction of the oxalodihydrazonyl dihalide derivatives $\mathbf{2 2}$ with sodium azide in aqueous dimethylformamide at room temperature afforded the corresponding $N, N$-diaryloxalodihydrazonyl diazides 23 in $80-85 \%$ yields. Reduction of $\mathbf{2 3}$ with lithium aluminum hydride in ether yielded the diamidrazone derivatives $\mathbf{2 4}$ in $65-\mathbf{7 2 \%}$ yields. Reactions of $\mathbf{2 4}$ with acyl chlorides $\mathbf{2 5}$ in refluxing benzene gave the 3,3`-bi-1,2,4-triazole derivatives $\mathbf{2 6}$ in $43-60 \%$ yields (Scheme 8 ). ${ }^{42}$
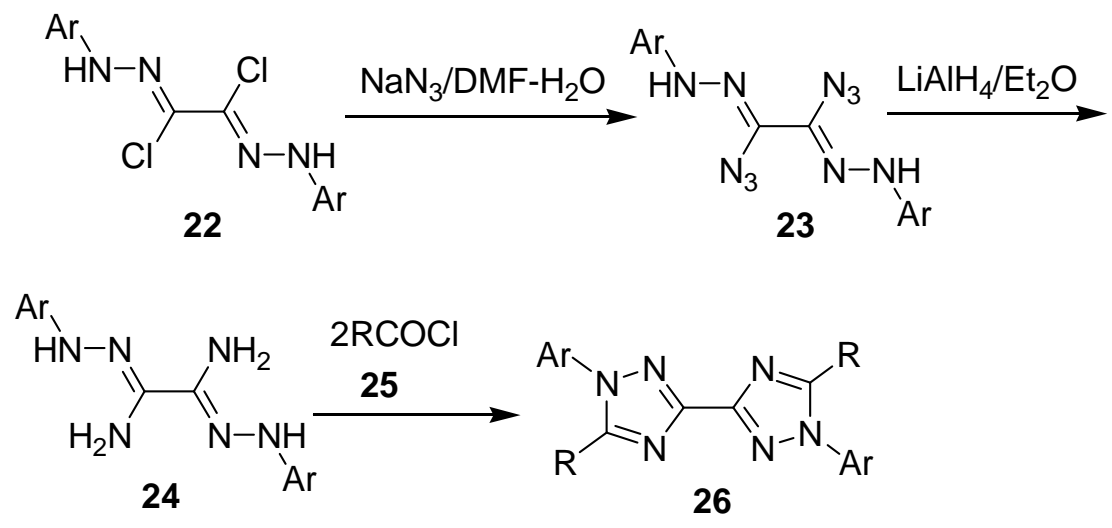

$$
\mathrm{Ar}=\mathrm{Ph}, 4-\mathrm{ClC}_{6} \mathrm{H}_{4}, \mathrm{R}=\mathrm{Ph}, 4-\mathrm{XC}_{6} \mathrm{H}_{4}, 3-\mathrm{O}_{2} \mathrm{NC}_{6} \mathrm{H}_{4}, \mathrm{ClCH}_{2}
$$

\section{Scheme 8}


3,3`-Bi-1,2,4-triazolo[3,4-a]isoquinolines 28 were prepared in good yields via 1,3-dipolar cycloaddition reaction of dihydrazonoyl dihalides 22 with 3,4-dihydroisoquinolines 27 (Scheme 9). ${ }^{43}$

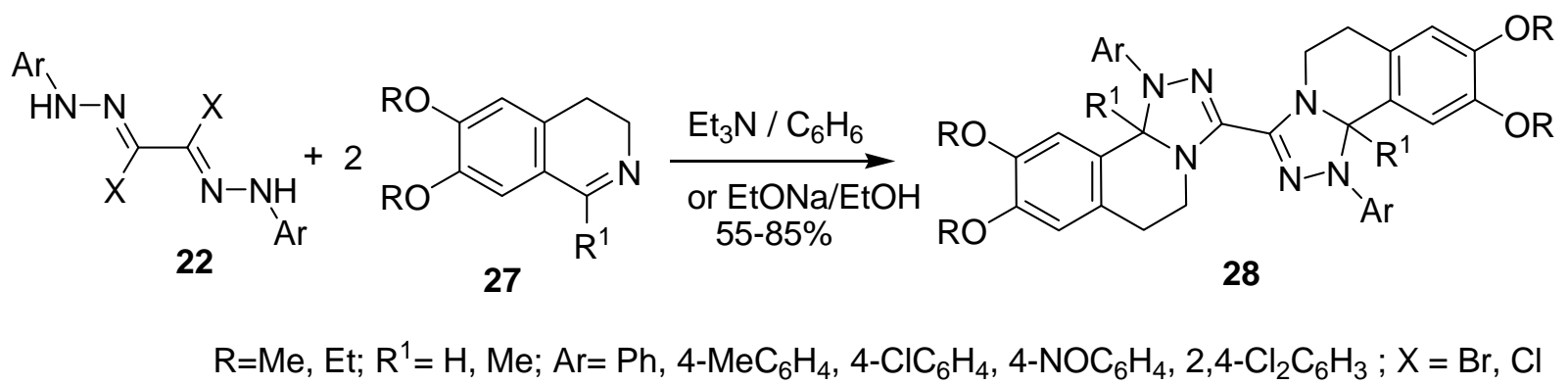

\section{Scheme 9}

The bi-1,2,4-triazolo[a,c]quinoxaline derivatives $\mathbf{3 2}$ were prepared via reaction of 2,3-dichloroquinoxaline $\mathbf{2 9}$ with the acid hydrazide derivatives $\mathbf{3 0}$, followed by thermal cyclization via refluxing the resulting quinoxaline derivatives 31 with phosphorus oxychloride in an oil bath at $140{ }^{\circ} \mathrm{C}$ (Scheme 10). ${ }^{44}$<smiles>[R]C(=O)NNNc1nc2ccc(CC)cc2nc1NNNC([R])=O</smiles>

\section{Scheme 10}

$\mathrm{R}=\mathrm{Me}, \mathrm{Ph}, 2-\mathrm{ClC}_{6} \mathrm{H}_{4}, 2-\mathrm{OHC}_{6} \mathrm{H}_{4}, 4-\mathrm{NH}_{2} \mathrm{C}_{6} \mathrm{H}_{4}, 2-\mathrm{OH}-4-\mathrm{SO}_{3} \mathrm{HC}_{6} \mathrm{H}_{3}$

Reaction of oxalic acid dihydrazide $\mathbf{3 3}$ with isothiocyanates yielded the respective thiosemicarbazide derivatives 34. Cyclization of $\mathbf{3 4}$ in alkaline medium afforded the corresponding 4,4'-substituted-5,5'mercapto-3,3`-bi-1,2,4-triazole 35 (Scheme 11). ${ }^{45}$

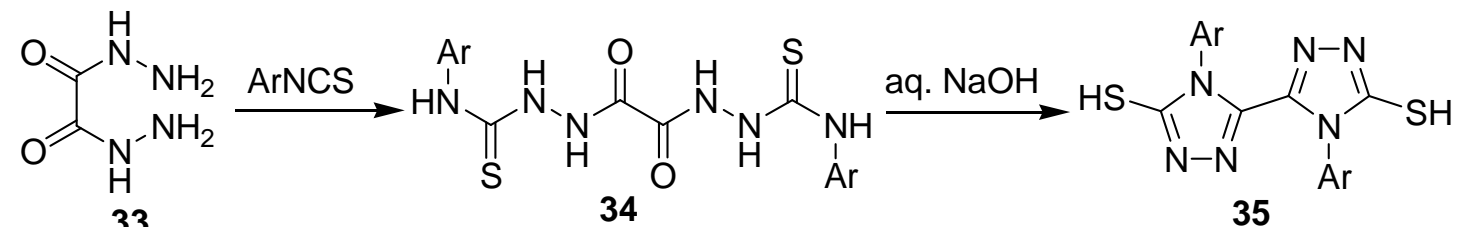

\section{Scheme 11}

Reaction of oxalo-bis-hydrazide 33 with carbon disulfide followed with hydrazines afforded the 3,3`-bi-1,2,4triazoles 37. Also reaction of the oxalo-bishydrazide $\mathbf{3 3}$ with carboxylic acids gave the bioxadiazoles $\mathbf{3 8}$ which on treatment with hydrazines or amines yielded the 3,3`-bi-1,2,4-triazole derivatives 39 (Scheme 12). ${ }^{15}$ 
<smiles>[R]n1c(S)nnc1-c1nnc(S)n1[R]</smiles>

33

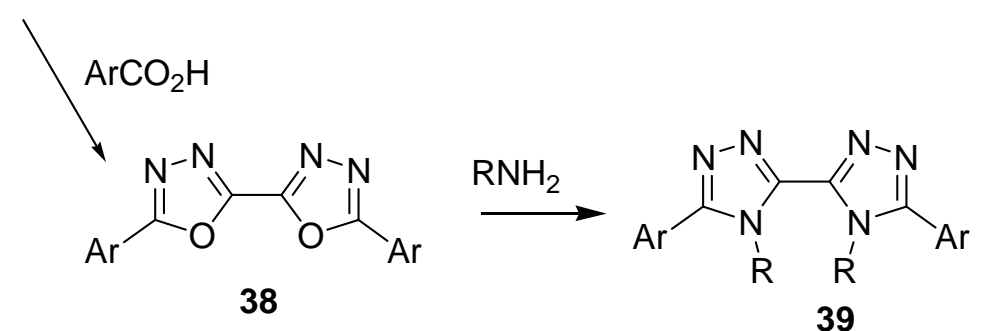

$$
\mathrm{Ar}=2-\mathrm{ClC}_{6} \mathrm{H}_{4}, 4-\mathrm{ClC}_{6} \mathrm{H}_{4} ; \mathrm{R}=\mathrm{NH}_{2}, \mathrm{NHPh}
$$

\section{Scheme 12}

The 3,3`-bi-1,2,4-triazole derivative $\mathbf{4 1}$ was prepared in moderate yield by reaction of $N, N^{`}$ diphenyloxalohydrazonoyl dichloride 22 with 2-(methylthio(phenylamino)methylene)-malononitrile 40 in refluxing ethanol and triethylamine (Scheme 13). ${ }^{46}$

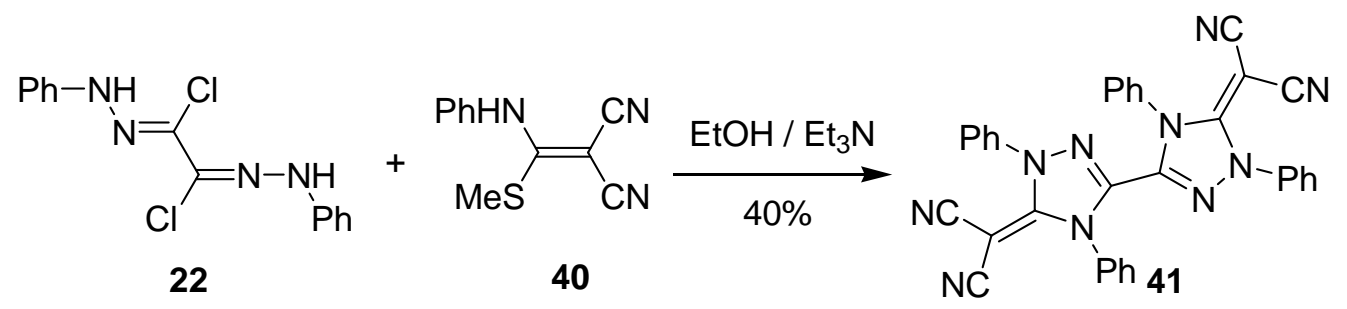

\section{Scheme 13}

4,4`,5,5`-Tetraamino-3,3`-bi-1,2,4-triazole 43 was synthesized from heating 1,3-diaminoguanidine monohydrochloride $\mathbf{4 2}$ with oxalic acid in the presence of polyphosphoric acid (PPA). Heating of $\mathbf{4 3}$ in the presence of acetic anhydride, yielded the corresponding tetracetamido-3,3`-bi-1,2,4-triazole derivative 44 in $98 \%$ (Scheme 14). ${ }^{47-49}$

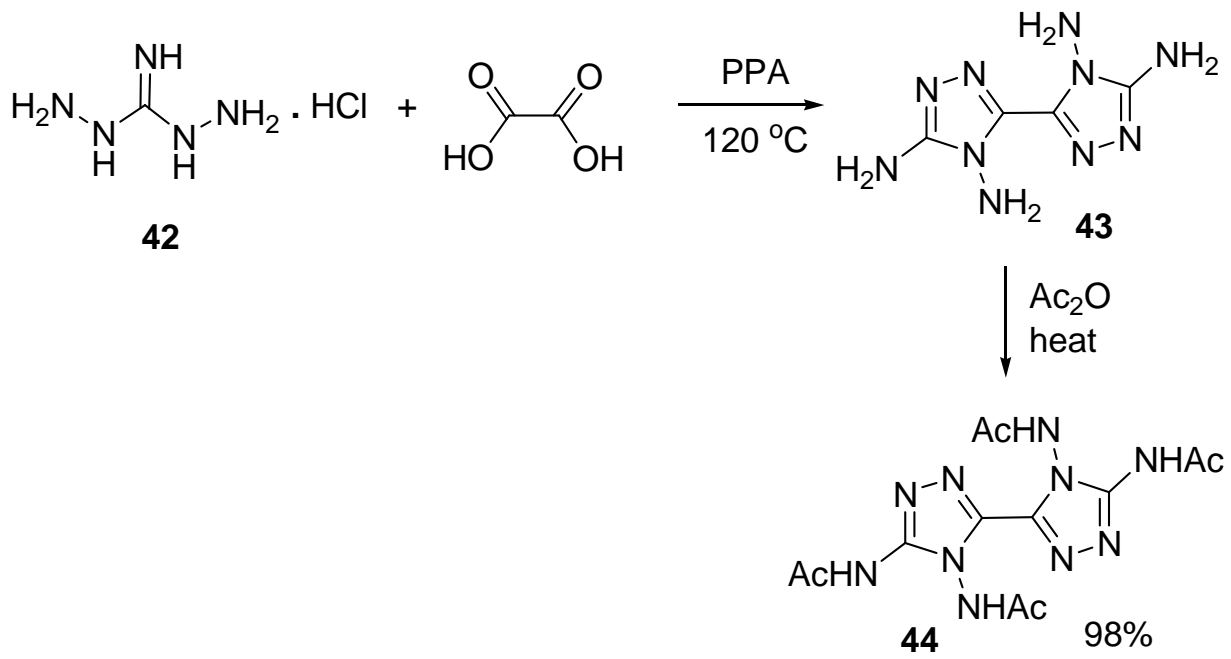

\section{Scheme 14}




\section{5. $3,4^{`}$-Bi-triazoles}

Heating of the 1,2,3-triazolylhydrazides 45 with ammonium acetate and aromatic aldehydes in ethanol catalyzed by 20 mol\% $\mathrm{ZrOCl}_{2} .8 \mathrm{H}_{2} \mathrm{O}$, afforded the corresponding 3,4'-bitriazole derivatives 46 in 80 - $85 \%$ yields (Scheme 15). ${ }^{50}$<smiles>[R]N1CCC(n2cc(C(=O)NN)nn2)CC1</smiles>

45

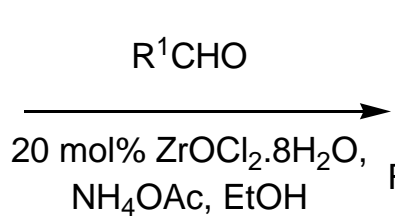

$\mathrm{NH}_{4} \mathrm{OAc}, \mathrm{EtOH}$

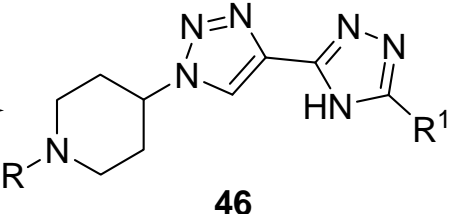

46

$$
\mathrm{R}=\mathrm{Boc}, \mathrm{SO}_{2} \mathrm{Me}, \mathrm{COCH}_{3} ; \mathrm{R}^{1}=\mathrm{Ph}, 4-\mathrm{MeC}_{6} \mathrm{H}_{4}, 4-\mathrm{MeOC}_{6} \mathrm{H}_{4}, 4-\mathrm{ClC}_{6} \mathrm{H}_{4}, 4-\mathrm{O}_{2} \mathrm{NC}_{6} \mathrm{H}_{4}
$$

\section{Scheme 15}

Heating diformylhydrazine 47 and 3-amino-1H-1,2,4-triazole 48 in a Teflon-lined stainless steel autoclave in a furnace at $170^{\circ} \mathrm{C}$ for 3 days yielded the $3,4^{\circ}$-bitriazole derivative 49 in $80 \%$ yield (Scheme 16). ${ }^{51}$

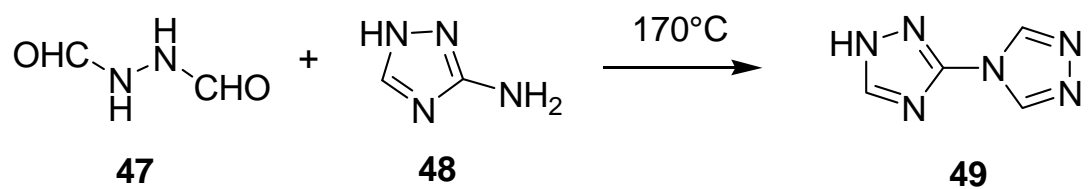

\section{Scheme 16}

\subsection{4,4'-Bi-triazoles}

The 4,4'-bi(1,2,3-triazole) derivatives 52 were prepared in high yields directly from 1,4bis(trimethylsilyl)butadiyne $\mathbf{5 0}$ by reaction with two equivalents of the azides $\mathbf{5 1}$ in $\mathrm{H}_{2} \mathrm{O} / t$ - $\mathrm{BuOH}$ in the presence of $\mathrm{K}_{2} \mathrm{CO}_{3}$ and a catalytic amount of $\mathrm{CuSO}_{4}$. The reaction proceeded via tandem deprotection/click transformations and the presence of $\mathrm{K}_{2} \mathrm{CO}_{3}$ allowed the in situ removal of the TMS group of the alkyne reactants (Scheme 17). The 4,4'-bi(1,2,3-triazole) derivatives 52 were reported as bidentate chelators by forming stable $\mathrm{Ru}(\mathrm{II})$ complexes $\mathbf{5 3}$ which are coordinatively symmetrical, largely optically transparent and nonfluorescent. Compound $\mathbf{5 2}(\mathrm{R}=\mathrm{Et})$ formed $\mathrm{Re}(\mathrm{I})$ complex $\mathbf{5 4}$ by its reaction with Rhenium(I) pentacarbonyl chloride $\mathrm{Re}(\mathrm{CO})_{5} \mathrm{Cl}$, which was useful for homogeneous- and electro-catalysis fields (Scheme 17). ${ }^{52-56}$ 


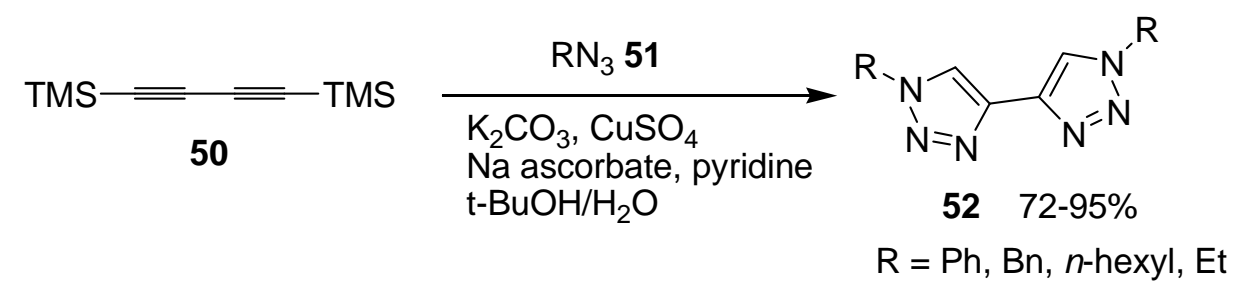

\section{Scheme 17}

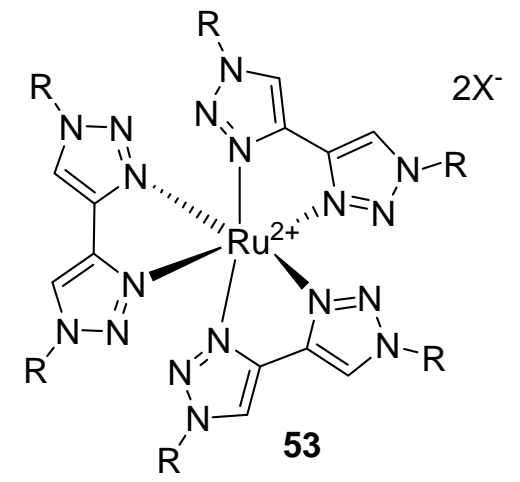

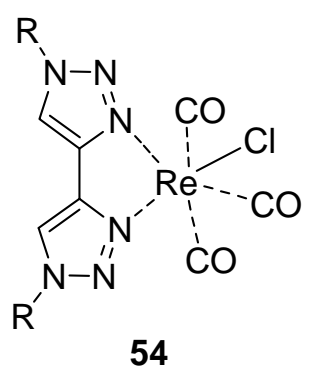

An alternative synthesis of 1,1'-diphenyl-4,4'-bi(1,2,3-triazole) $52(R=P h)$ was reported in two steps; firstly reaction of anilines with tert-butyl nitrite then trimethylsilyl azide to obtain aryl azide. Afterward, 1,4bis(trimethylsilyl)buta-1,3-diyne 50, pyridine, potassium carbonate, $\mathrm{CuSO}_{4} .5 \mathrm{H}_{2} \mathrm{O}$ and sodium ascorbate in $\mathrm{H}_{2} \mathrm{O}$ were added to give $\mathbf{5 5}$ in $\mathbf{5 1 - 8 5 \%}$ yield (Scheme 18). ${ }^{57}$

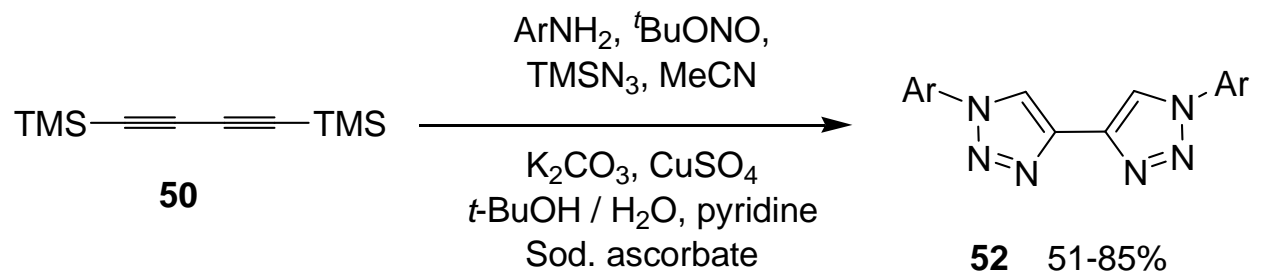

\section{Scheme 18}

$\operatorname{Ar}=\mathrm{Ph}$, mesityl, 2,6-diisopropylphenyl

Using the click copper-catalyzed azide alkyne cycloaddition (CUAAC) condition, the reaction of 1,4bis(trimethylsilyl)butadiyne $\mathbf{5 0}$ with two equivalents of epi-azido quinine $\mathbf{5 5}$ led to the formation of the 4,4'bi(1,2,3-triazole) derivative 56 in excellent yield (Scheme 19). The bitriazole 56 was applied as ligand in several copper-catalyzed asymmetric Michael-type addition reactions. ${ }^{58}$

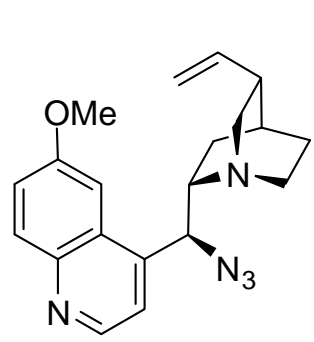

55

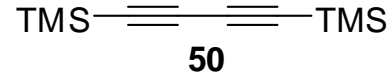
1) $\mathrm{K}_{2} \mathrm{CO}_{3}, \mathrm{CuSO}_{4}$ $t$ - $\mathrm{BuOH} / \mathrm{H}_{2} \mathrm{O}$, pyridine
2) aq. $\mathrm{NH}_{3}, \mathrm{DCM}$
3) $\mathrm{Na}_{2} \mathrm{~S}$

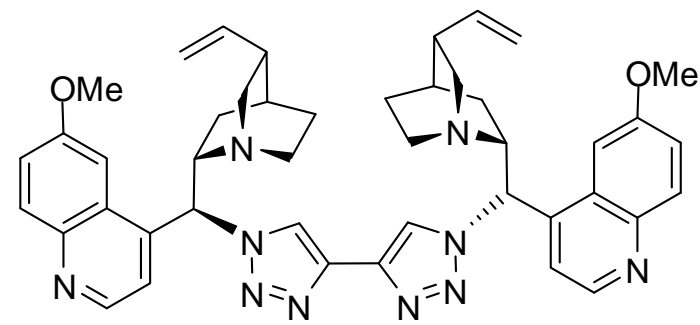

$5688 \%$

\section{Scheme 19}


Dipolar cycloaddition of perfluorohexa-2,4-diyne 57 with azides 51 in hexane afforded the 4,4'-bi-1,2,3bitriazole derivatives 58 in good yields. In addition, the 4,4'-bi-1H-1,2,3-triazole derivatives 59 were synthesized by the Cul-catalyzed click reaction between buta-1,3-diyne and the aryl azides 51 (Scheme 20). ${ }^{59,60}$

\section{Scheme 20}

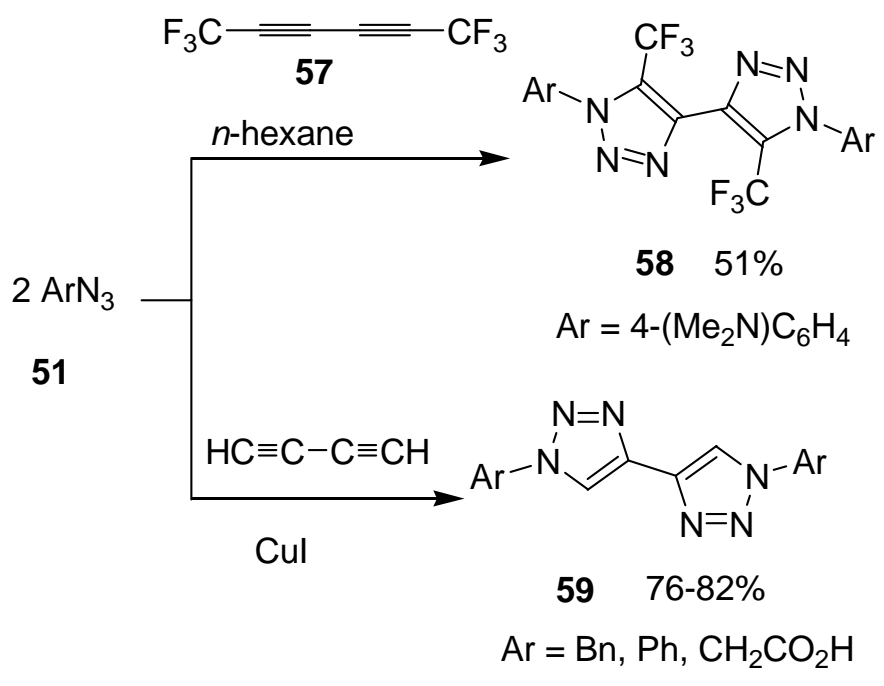

Fiandanese et al. reported the synthesis of the unsymmetrically substituted 4,4'-bi-1,2,3-triazole derivatives $\mathbf{6 2}$ from the reaction of 1-trimethylsilyl-1,3-butadiyne $\mathbf{6 0}$ with the azide derivatives $\mathbf{5 1}$. Reaction of the azides 51 with compound 60 in the presence of $\mathrm{Cu}(\mathrm{OAc})_{2}$, as a catalyst, in water provided $51-92 \%$ yields of the corresponding 1,4-triazole adducts 61 . Treatment of compounds 61 with the azides 51 in THF, at room temperature employing Cul catalyst and TBAF, in the presence of 1,1,4,7,7-pentamethyl-diethylenetriamine, led to the formation of the 4,4'-bitriazole derivatives 62 in $52-86 \%$ yields (Scheme 21). ${ }^{61}$

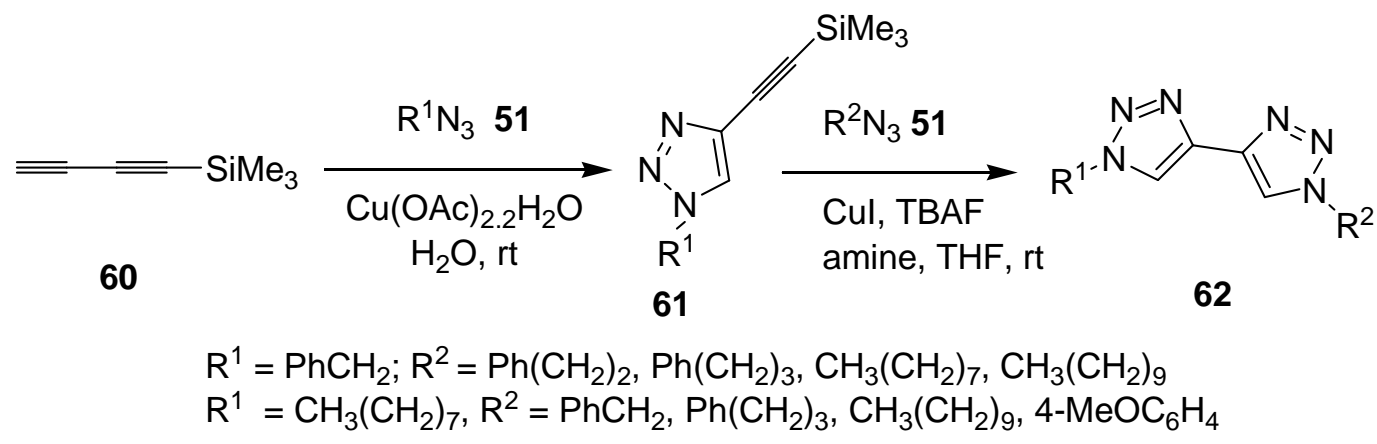

\section{Scheme 21}

The 4,4'-bi-1,2,3-triazole derivatives 64 were obtained smoothly and in high yields by cycloaddition reactions of compound $\mathbf{6 3}$ with alkyl azides 51 (Scheme 22). ${ }^{62}$ 


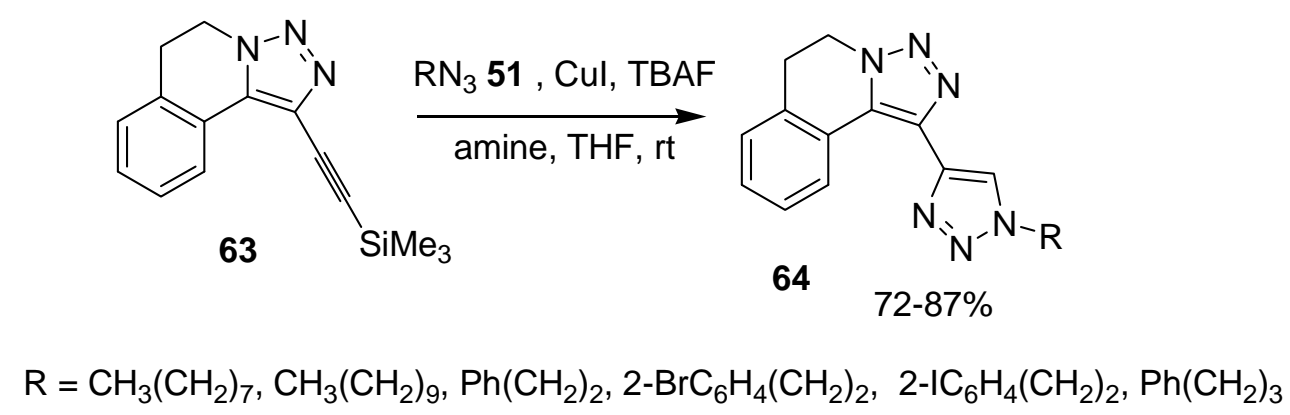

\section{Scheme 22}

4,4-Bi-1,2,3-triazole 67 was synthesized in two steps from 1,4-dichloro-2-butyne 65 with sodium azide to give 4-ethynyl-1H-1,2,3-triazole 66 as an intermediate via an azabutatriene type rearrangement. Compound 67 was obtained from 66 via "click chemistry" with trimethylsilyl azide (Scheme 23). ${ }^{63}$ The 4,4'-1H-1H-bi-1,2,3triazole 67 was reported as capable of mimicking the hydrogen bonding of water in the solid state and was able to conduct protons in the presence of poly(ethylene oxides) under anhydrous conditions. The bitriazole 67 was found to have sufficient thermal and electrochemical stability for fuel cell applications. ${ }^{63}$

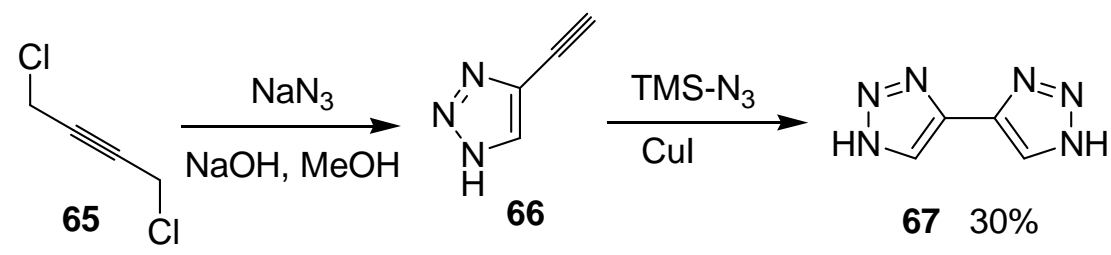

\section{Scheme 23}

4,4`-Bi-1,2,4-triazole derivatives 69 were prepared by Raney nickel catalyzed desulfurization reaction of the bis-s-triazolothiadiazines 68 (Scheme 24). ${ }^{37}$

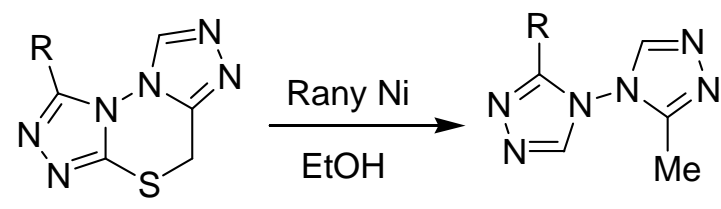

68

$\mathrm{R}=\mathrm{H}, \mathrm{Me}$

$6960 \%$

\section{Scheme 24}

$\alpha-1,2,4$-Triazolylcarbonyl arylhydrazines 71 were synthesized via nucleophilic substitution reaction of the corresponding $\alpha$-(chloroformyl)arylhydrazine hydrochlorides 70 with $1 H$-1,2,4-triazole. Cycloaddition of 71 with 1,2,4-triazole at $60^{\circ} \mathrm{C}$ and in the absence of base gave the 2,2'-diaryl-4,4'-bi-1,2,4-triazole derivatives 72 in low yields (13-18\%) (Scheme 25). ${ }^{64}$ 
<smiles>NN([Al])C(=O)Cl</smiles>

70

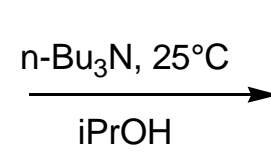
$\mathrm{iPrOH}$

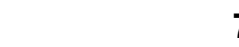

$7132-70 \%$

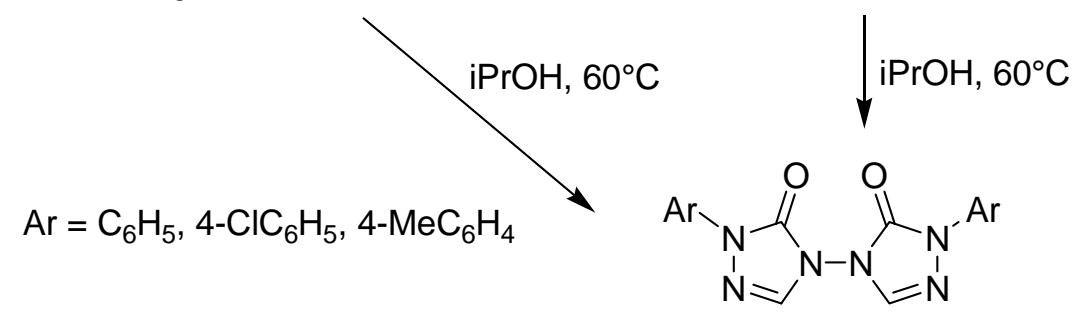

72

$13-18 \%$

\section{Scheme 25}

Heating of $N, N$-dimethylformamide azine dihydrochloride 73 with 4-amino-1,2,4-triazole 74 in benzene gave 4,4'-bi-1,2,4-triazole 75 in significant yield (73\%) via direct transamination. Treatment of 75 with iodine monochloride in water at r.t., resulted in the formation of tetraiodo-4,4-bi-1,2,4-triazole 76 in $85 \%$ yield (Scheme 26). ${ }^{65-67} \mathrm{~N}$-Quaternization of the bi-1,2,4-triazole 75 with methyl iodide gave the corresponding iodide salt 77 in high yield. ${ }^{68}$ The application of the 1,1'-dimethyl-4,4'-bi-1,2,4-triazolium bitriazolium diiodide as chelating $N$-heterocyclic carbene ligand for ruthenium(II), palladium(II), and rhodium(II) to form the corresponding complexes $78-80$ was reported. ${ }^{21}$

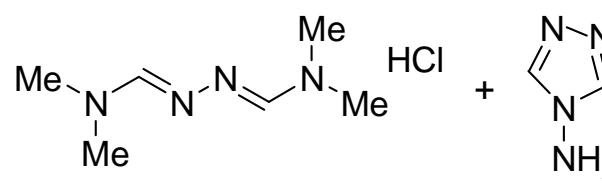

73

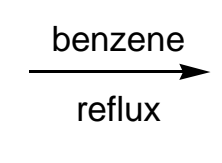

$75 \quad 73 \%$<smiles>C=NN(C)C</smiles>

79

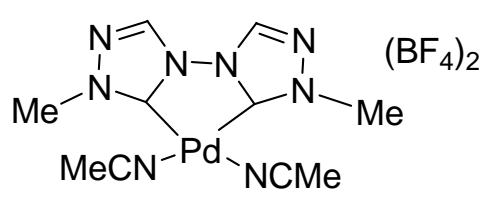

80

\section{Scheme 26}


When an equimolar mixture of appropriate hydrazonoyl halide $\mathbf{8 1}$ and 1,4-diphenyl-2,3-diaza-I,3butadiene 82a was refluxed in dry benzene in the presence of triethylamine, it afforded the cycloadduct 4(phenylmethylene)amino-1,2,4-triazole derivatives 83. Treatment of the cycloadducts 83 with the hydrazonoyl halides $\mathbf{8 1}$ afforded the corresponding 5,5`-diphenyl-1,1',3,3'-tetrasubstituted 4,4'-bi-1H-1,2,4-triazole derivatives 84 in good yields (Scheme 27). ${ }^{69}$

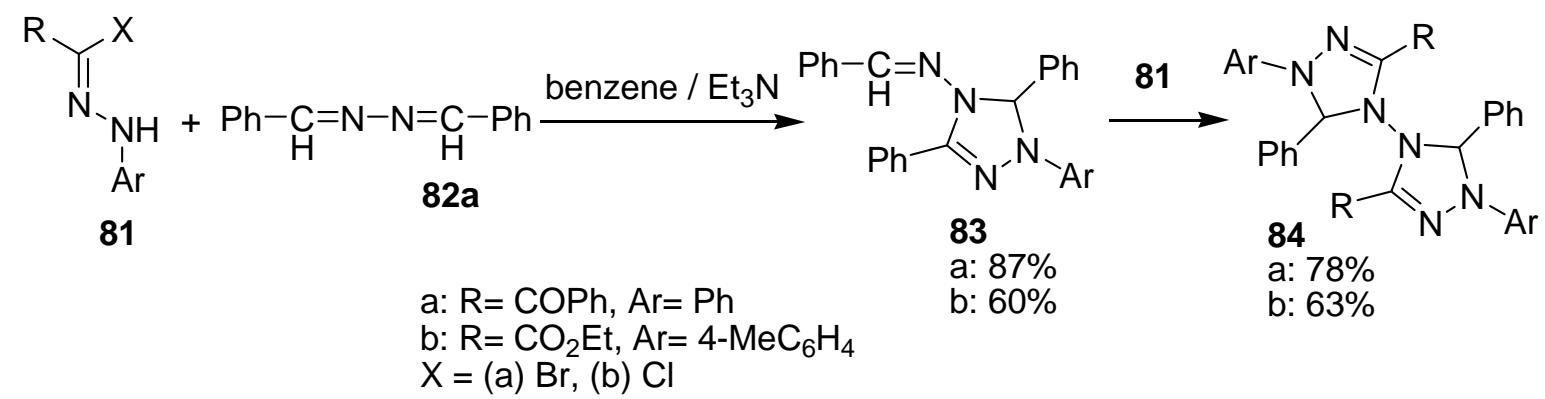

\section{Scheme 27}

The reaction between 4-amino-3,5-dimethyl-4H-1,2,4-triazole 85 and bis( $\alpha$-chlorobenzylidene)hydrazine 86 in refluxing xylene yielded 3,3`-dimethyl-5`,5'-diphenyl-4,4`-bi-4H-1,2,4-triazole 87. Initial nucleophilic displacement of chlorine in $\mathbf{8 6}$ by the amino group followed by an intramolecular ring closure and subsequent elimination of diazoethane to give $\mathbf{8 9}$ was disclosed. Repeating this reaction at the second imidoyl chloride centre yielded the 4,4'-bi-1,2,4-triazole derivative 90 (Scheme 28). ${ }^{70}$

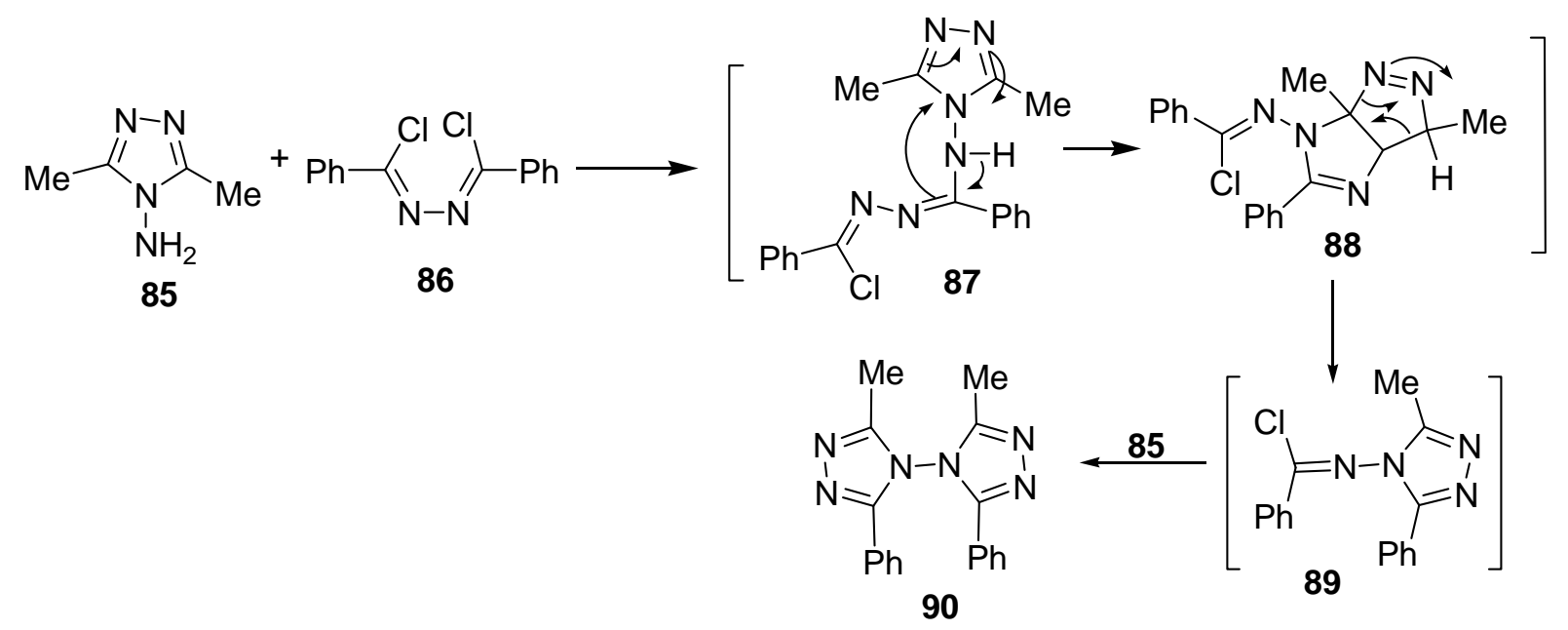

\section{Scheme 28}

Heating the three component reaction of 3-aryl-5-methyl-1,3,4-oxadiazol-2(3H)-ones 91 with thiocarbazide 92 and aliphatic carboxylic acids, resulted in the formation of the 4,4-bi-1,2,4-triazole derivatives 95 via the intermediates 93 and 94 as shown in Scheme $29 .^{71}$ 


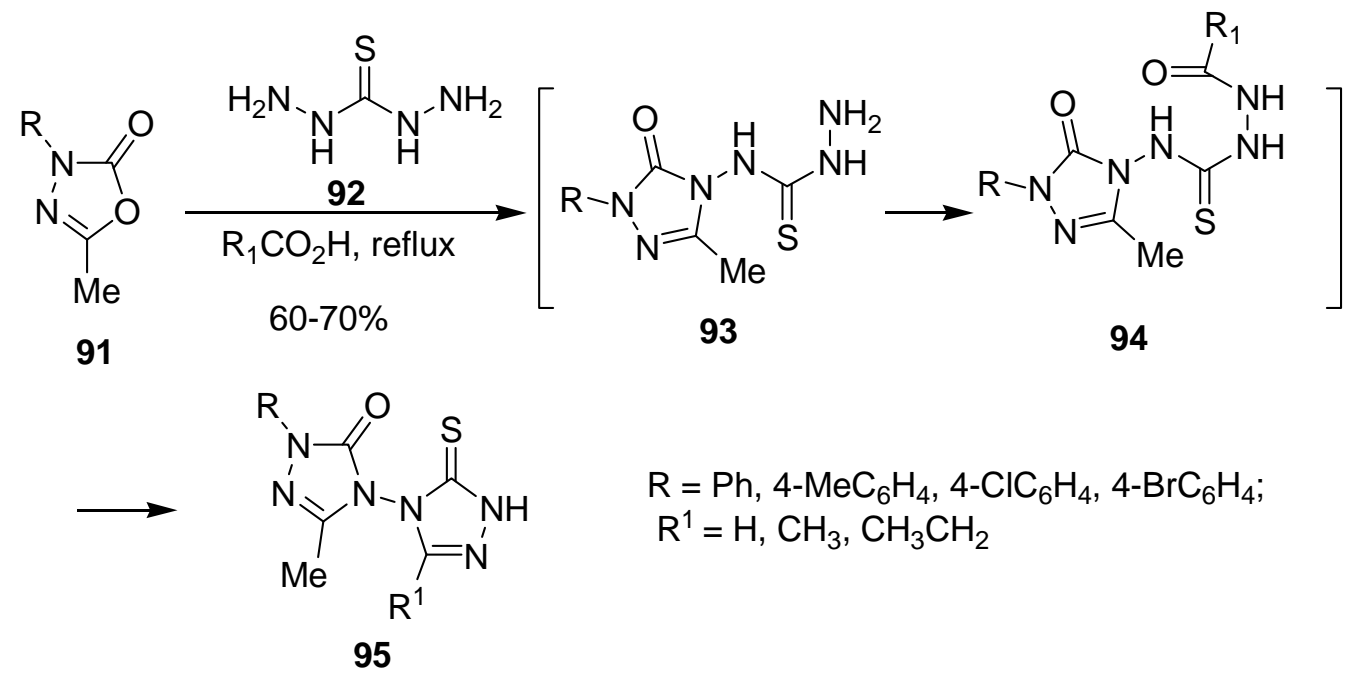

\section{Scheme 29}

Condensation of dinitromethane with glyoxal afforded 1,1,4,4-tetranitro-1,3-butadiene 96. Reaction of the latter compound with sodium azide led to formation of 4,4'-bi-1,2,3-triazole derivative 98 via 1,1,4,4tetranitro-2,3-butanediol intermediate 97 (Scheme 30). ${ }^{72}$

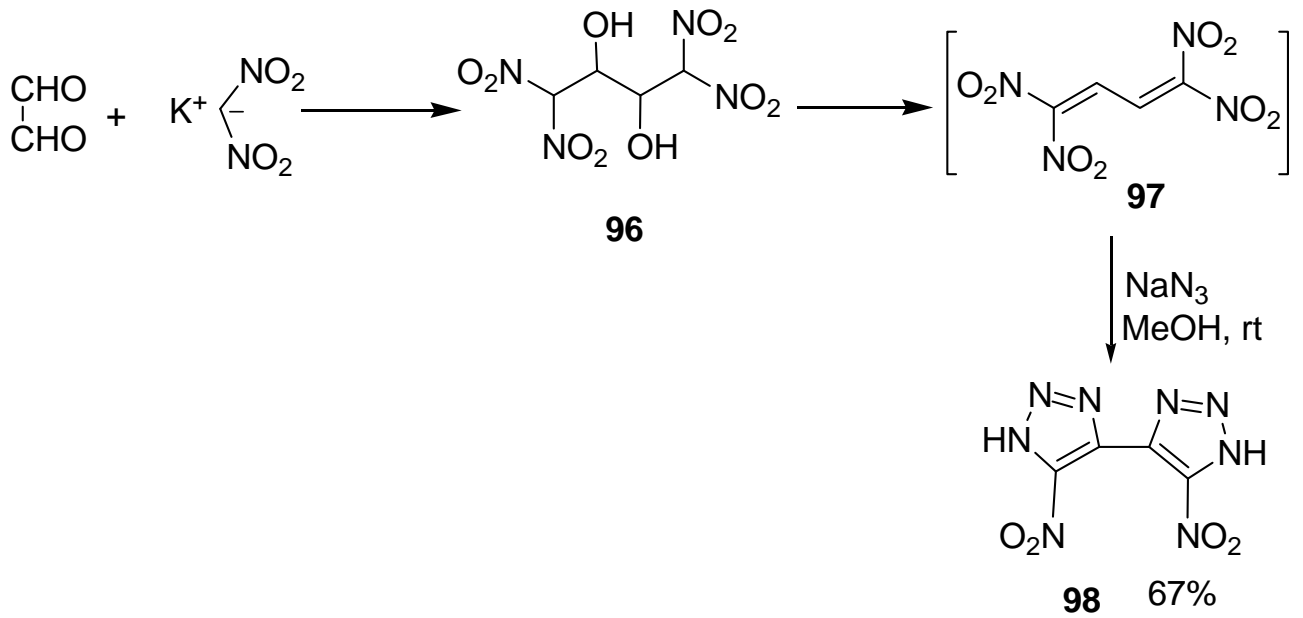

\section{Scheme 30}

Thermal rearrangement of 3-acylisoxazole arylhydrazones 100 , prepared by heating of 1-(5methylisoxazol-3-yl)ethanone 99 with phenylhydrazine in ethanol, allowed facile preparation of 1-(1,2,3triazol-4-yl)propan-2-ones 101. Reaction of the 1,2,3-triazolylpropanone derivatives 101 with isoamyl nitrite then arylhydrazine produced $\alpha$-hydroxyiminohydrazones 102. Reaction of $\mathbf{1 0 2}$ with phosphorus pentachloride afforded 4,4'-bi-1,2,3-triazoles 103 (Scheme 31). ${ }^{73}$ 
<smiles>CC(=O)c1cc(C)on1</smiles>

99<smiles>CCO[R10](=O)c1ccccc1</smiles>

100

101

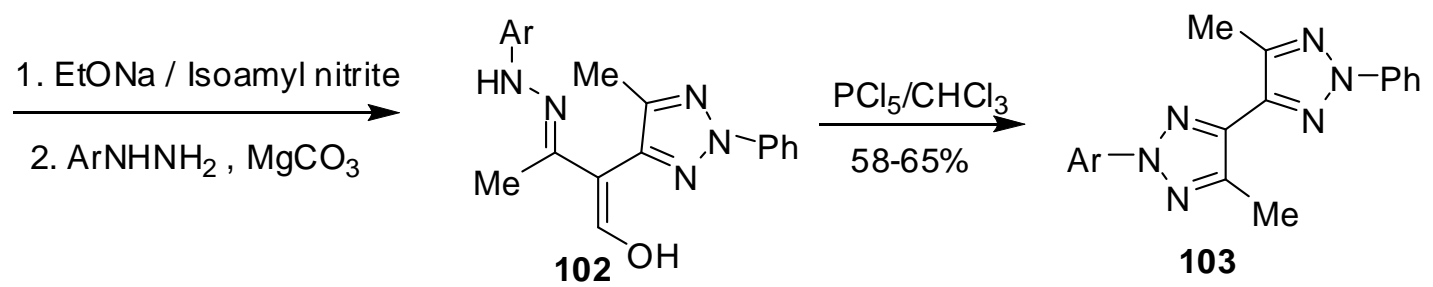

$\mathrm{Ar}=\mathrm{Ph} ; 2-\mathrm{Cl}, 3-\mathrm{Cl}, 4-\mathrm{Cl}\left(\mathrm{C}_{6} \mathrm{H}_{4}\right) ; 2-\mathrm{Br}, 3-\mathrm{Br}, 4-\mathrm{Br}\left(\mathrm{C}_{6} \mathrm{H}_{4}\right) ; 4-\mathrm{O}_{2} \mathrm{NC}_{6} \mathrm{H}_{4}$

\section{Scheme 31}

Copper(I)-catalyzed alkyne-azide 'click' [2+3] cycloaddition reactions (CuAAC) method was applied in the synthesis of nonsymmetrical-substituted 4,4'-bis(1,2,3-triazolium) salts 105 by reaction of 3-alkyl-4-ethynyl-1,2,3triazolium salts 104 with alkyl and aryl azides (Scheme 32$).^{74}$

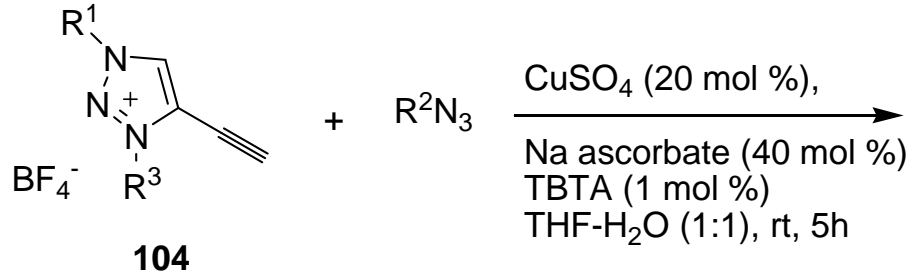

104

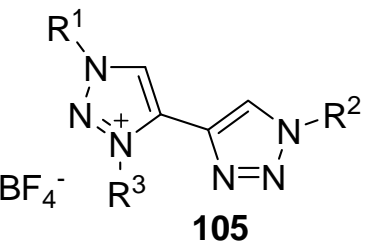

$75-95 \%$

$$
\mathrm{R}^{1}=\mathrm{Bn}, 4-\mathrm{t}-\mathrm{BuC}_{6} \mathrm{H}_{4} \mathrm{CH}_{2}, 4-\mathrm{NCC}_{6} \mathrm{H}_{4} ; \mathrm{R}^{2}=\mathrm{Bn}, \mathrm{CH}_{2} \mathrm{C}_{6} \mathrm{H}_{4}-\mathrm{t}-\mathrm{Bu}, \mathrm{ph} ; \mathrm{R}^{3}=\mathrm{Me}, \mathrm{Et}
$$

\section{Scheme 32}

\subsection{4,5'-Bi-triazoles}

The 4,5'-bitriazolyl acyclonucleosides 107 were synthesized in good yields via a one-step Huisgen cycloaddition reaction using sodium azide and the 5-alkynylyltriazole acyclonucleosides 106 in DMF at $90^{\circ} \mathrm{C}$ (Scheme 33). The synthesized bitriazolyl compounds exhibited potent antiviral activity against tobacco mosaic virus and were devoid of any notable toxicity. ${ }^{75}$ 
<smiles>[R]C#Cc1nc(C(N)=O)nn1COCCO</smiles>

106<smiles></smiles>

107

\section{$\mathrm{R}=\mathrm{Ph}, 4-\mathrm{MeC}_{6} \mathrm{H}_{4}, 4-\mathrm{MeOC}_{6} \mathrm{H}_{4}, 4-\mathrm{FC}_{6} \mathrm{H}_{4}, 4-\mathrm{CH}_{3}\left(\mathrm{CH}_{2}\right)_{3} \mathrm{C}_{6} \mathrm{H}_{4}$}

4- $\mathrm{CH}_{3}\left(\mathrm{CH}_{2}\right)_{4} \mathrm{C}_{6} \mathrm{H}_{4}, 4-\mathrm{F}_{3} \mathrm{CC}_{6} \mathrm{H}_{4}, 3-\mathrm{F}_{3} \mathrm{CC}_{6} \mathrm{H}_{4}$, 2-thienyl, 1-cyclohexenyl

\section{Scheme 33}

The 4,5'-bitriazolyl acyclonucleosides 109 were synthesized in excellent yields via the copper catalyzed cycloaddition reaction of aryl azides and the 5-acetynylyltriazole acyclonucleoside 108 in THF-water followed by ammonolysis with $\mathrm{NH}_{3} / \mathrm{MeOH}$ mixture (Scheme 34). The synthesized compounds exhibited powerful antiproliferative effects on numerous cancer cell lines. ${ }^{76}$<smiles>C#Cc1nc(C(=O)OC)nn1COCCOC(C)=O</smiles>

108
1) $\mathrm{RN}_{3}, \mathrm{CuSO}_{4} .5 \mathrm{H}_{2} \mathrm{O}$ sod. ascorbate

$\mathrm{THF} / \mathrm{H}_{2} \mathrm{O} 1 / 3_{3}, 40^{\circ} \mathrm{C}$

2) $\mathrm{NH}_{3} / \mathrm{CH}_{3} \mathrm{OH}, \mathrm{rt}$<smiles>[R]n1cc(-c2nc(C(N)=O)nn2COCCO)nn1</smiles>

$10973-99 \%$

$\mathrm{R}=\mathrm{Ph}, 4-\mathrm{MeC}_{6} \mathrm{H}_{4}, 4-\mathrm{MeOC}_{6} \mathrm{H}_{4}, 4-\mathrm{CF}_{3} \mathrm{C}_{6} \mathrm{H}_{4}, 4-\mathrm{NO}_{2} \mathrm{C}_{6} \mathrm{H}_{4}, 3-\mathrm{F}_{3} \mathrm{CC}_{6} \mathrm{H}_{4}$, benzyl, 1-naphthalenyl, 1-methylpyrenyl

\section{Scheme 34}

\subsection{5,5`-Bitriazoles}

Reaction of the 1,4-diazabutadiene derivative $\mathbf{8 2}$ b with a 1:2 molar amount of the hydrazonoyl chlorides $\mathbf{8 1}$ resulted in the formation of the 5,5'-bi-1,2,4-triazoline derivatives 110 in moderate yields (Scheme 35). ${ }^{69}$

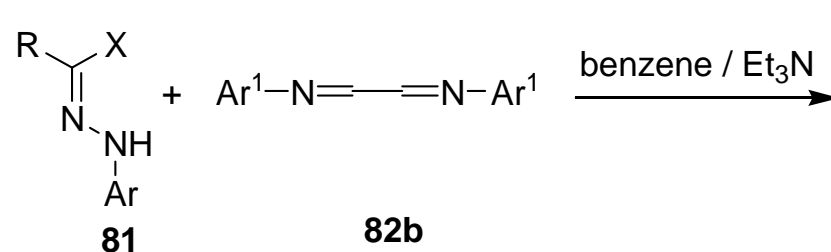

$\mathrm{Ar}^{1}=4-\mathrm{MeC}_{6} \mathrm{H}_{4}$<smiles>[R]C1=NN([Al])C(C2N([Al])N=C([R])N2[Al])N1[Al]</smiles>

110a: $42 \%$

110b: $33 \%$

a: $\mathrm{R}=\mathrm{CO}_{2} \mathrm{Et}, \mathrm{Ar}=4-\mathrm{MeC}_{6} \mathrm{H}_{4}$

b: $\mathrm{R}=\mathrm{COCH}_{3}, \mathrm{Ar}=4-\mathrm{ClC}_{6} \mathrm{H}_{4}$

\section{Scheme 35}


Cycloaddition of phenylacetylene 5 and benzyl azide using catalytic amount of copper(I) iodide in the presence of $\mathrm{NaOH}$ yielded the 5,5 -bi-1,2,3-triazole derivative 111 via the intermediates 112-114 according to the reaction mechanism depicted in Scheme $36 .^{77}$

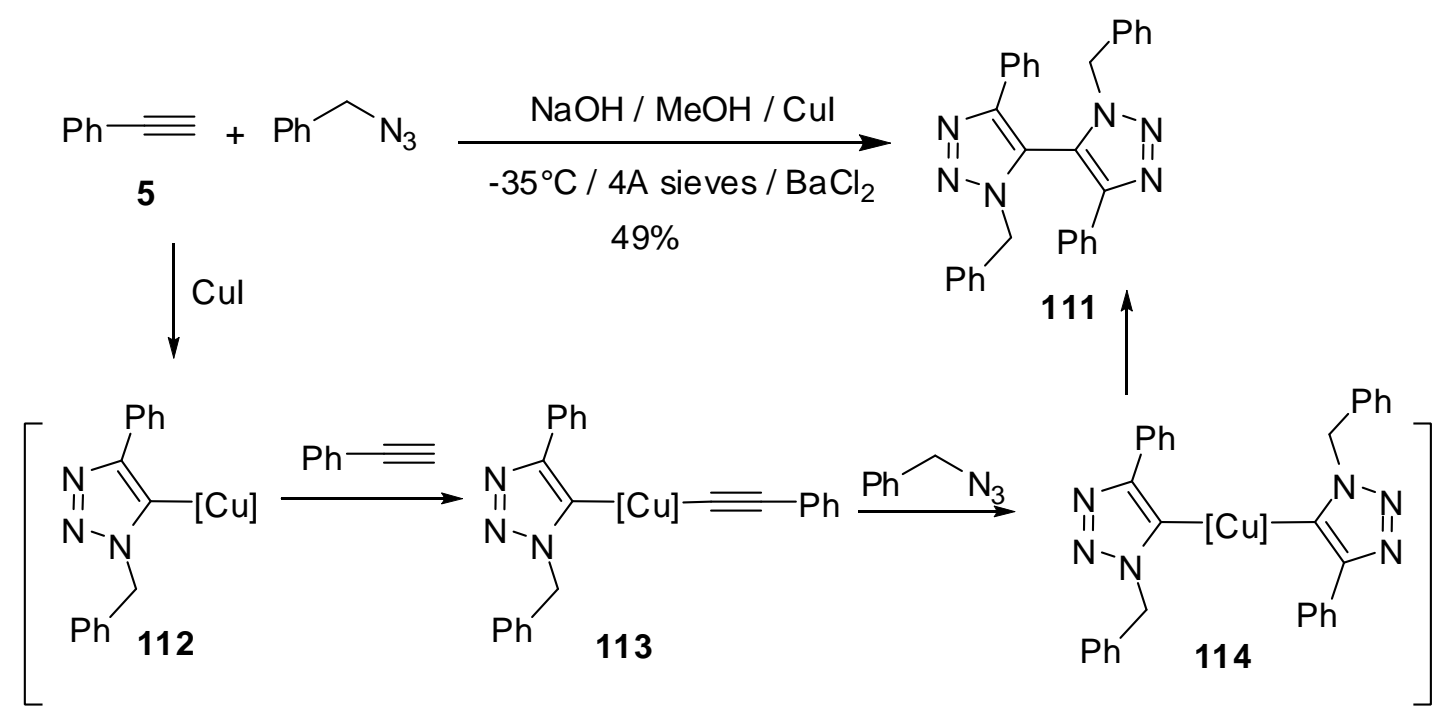

\section{Scheme 36}

The oxidative dimerization was extrapolated in the copper-mediated Huisgen reaction of the terminal alkynes $\mathbf{5}$ with azides $\mathbf{5 1}$ to yield the 5,5'-bi-1,2,3-triazole derivatives $\mathbf{1 1 5}$ under basic reaction conditions (Scheme 37). $^{78}$

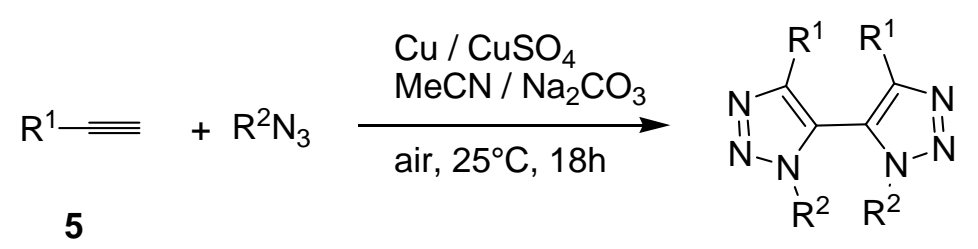

$$
11534-87 \%
$$

$$
\begin{aligned}
& \mathrm{R}^{1}=\mathrm{Ph}, 2-\mathrm{Br}-4-\mathrm{NO}_{2} \mathrm{C}_{6} \mathrm{H}_{3} ; \mathrm{PhOCH}_{2}, \mathrm{HOCH}_{2} \mathrm{CH}_{2} \\
& \mathrm{R}^{2}=\mathrm{PhCH}_{2},{ }^{t} \mathrm{BuOCOCH}_{2}, \mathrm{PhCH}_{2}, \mathrm{R}^{1}=, \mathrm{R}^{2}=\mathrm{PhCH}_{2},
\end{aligned}
$$

\section{Scheme 37}

Trimethylsilylacetylene $\mathbf{1 1 6}$ and 2-(3-thienyl)ethynyltrimethylsilane $\mathbf{1 1 8}$ were also reported as effective substrates for the cycloaddition with benzyl azide and oxidative dimerization to give the corresponding 5,5'bitriazole derivatives 117 and 119 in 25 and 38\% yields, respectively (Scheme 38). ${ }^{78}$ 
<smiles>c1ccc(Cn2nncc2-c2cnnn2Cc2ccccc2)cc1</smiles>

$11725 \%$

$$
\begin{aligned}
& \overline{116} \text { TMS } \\
& \frac{116}{\text { Cu powder (1 equiv) }} \\
& \mathrm{CuSO}_{4} \text { (1 equiv) } \\
& \mathrm{MeCN} / 2 \mathrm{M} \text { aq. }_{\mathrm{Na}_{2} \mathrm{CO}_{3}, \mathrm{rt}}
\end{aligned}
$$
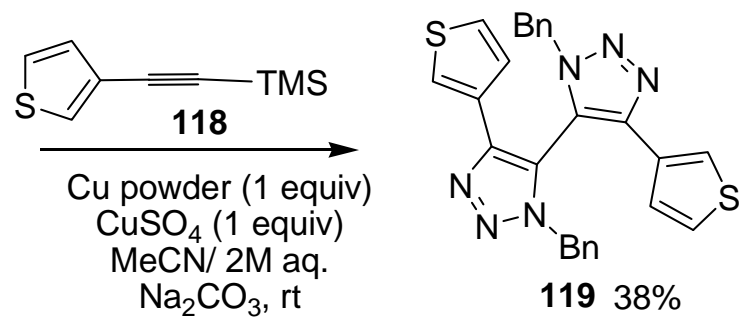

\section{Scheme 38}

Heating the oxalo-bis-hydrazide derivative $\mathbf{1 2 0}$ in water in the presence of bases, (alkali metal carbonates, or guanidinium or aminoguanidinium carbonates) at a molar ratio of 1:2 and subsequent acidification of the mixture resulted in the formation of the corresponding 5,5'-bi(3-nitroamino-1,2,4-triazole) salts 121 in excellent yields (Scheme 39). ${ }^{79-81}$

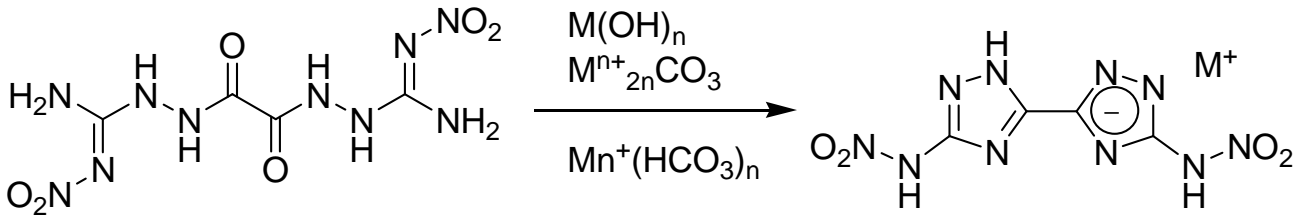

$\mathrm{M}=\mathrm{Na}, \mathrm{K}, \mathrm{NH}_{4}, \mathrm{NH}_{3} \mathrm{C}(=\mathrm{NH}) \mathrm{NH}_{2}, \mathrm{NH}_{3} \mathrm{NHC}(=\mathrm{NH}) \mathrm{NH}_{2}$

\section{Scheme 39}

3,3`-Diamino-5,5'-bi-1,2,4-triazole 123 (DABT) was synthesized from the reaction of oxalic acid and aminoguanidinium bicarbonate 122 in concentrated hydrochloric acid and subsequent cyclization in basic media. Oxidation of DABT 123 by Sandmeyer reaction via diazotization in sulfuric acid and subsequent reaction with sodium nitrite yielded 3,3'-dinitro-5,5'-bi-1,2,4-triazole (DNBT) 124 (Scheme 40). Oxidation of 3,3'-dinitro-5,5'-bi-1,2,4-triazole 124 in an buffered aqueous solution of oxone at $40{ }^{\circ} \mathrm{C}$ led to the selective oxidation to 3,3'-dinitro-5,5'-bi-1,2,4-triazole-1,1'-diol 125 (Scheme 40). The DNBT, as nitrogen-rich ligand, was employed in the development of energetic metal-organic frameworks (MOFs) of high density and thermal stability. ${ }^{82-87}$

Synthesis of 3,3`-dinitro-5,5`-bi-1,2,4-triazole-1,1`-diamine 127, as new explosive and energetic material, was reported employing amination conditions using either $O$-tosylhydroxylamine or $O$-mesitylenesulfonyl hydroxylamine reagents of the in situ ammonium salts of the 3,3`-dinitro-5,5'-bi-1,2,4-triazole 126 as outlined in Scheme $41 .^{88-90}$ 


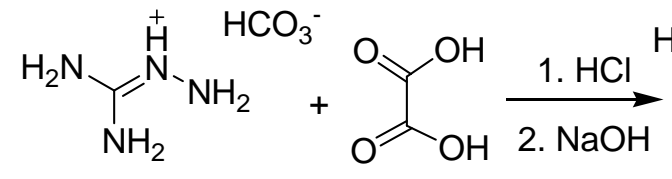

122

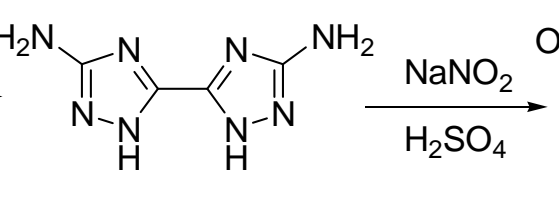

$12370 \%$

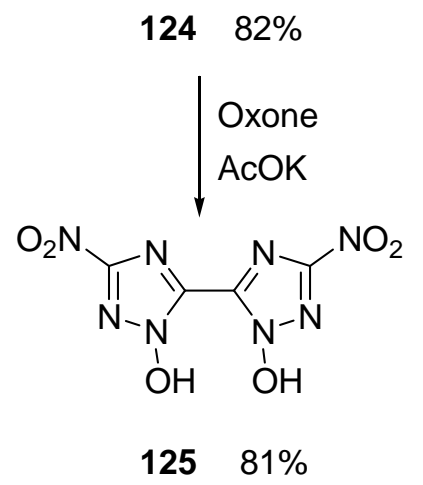

\section{Scheme 40}

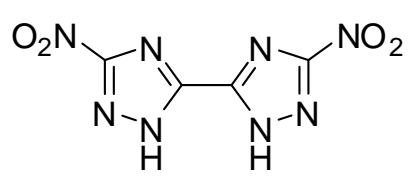

126

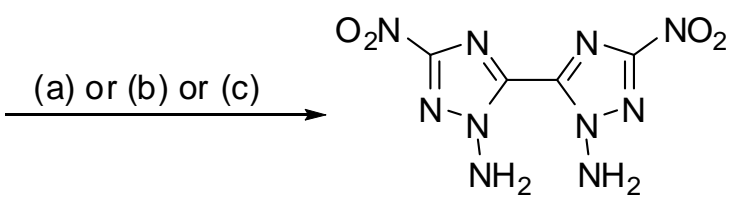

127

(a) $\mathrm{Et}_{4} \mathrm{NOH} / \mathrm{H}_{2} \mathrm{O}$ then O-mesitylenesulfonyl hydroxylamine/MeCN, yield $80 \%$

(b) $\mathrm{NH}_{3} / \mathrm{H}_{2} \mathrm{O}$ then O-tosylhydroxylamine/DMF/CHCl 3 yield $45 \%$

(c) $\mathrm{DBU} / \mathrm{CH}_{3} \mathrm{CN}$ then O-tosylhydroxylamine $/ \mathrm{CH}_{2} \mathrm{Cl}_{2}$, yield $56 \%$

\section{Scheme 41}

\section{Synthesis and Application of Bistriazole Systems}

\subsection{Bis-(1,2,3-triazoles)}

Copper promoted click chemistry was reported to be useful tool for the facile formation of bis(1,2,3triazoles). ${ }^{91}$ Copper catalyzed cycloaddition reaction between the alkyl azides 129, prepared by heating of bromide 128 with sodium azide in DMF at $100{ }^{\circ} \mathrm{C}$, and 4-bromo-1-butyne 130 in $\mathrm{H}_{2} \mathrm{O}$ at room temperature in the presence of $\mathrm{Cu}(\mathrm{OAc})_{2} \cdot \mathrm{H}_{2} \mathrm{O}$, led regioselectively to 4-(2-bromoethyl)-1,2,3-triazoles 131 in excellent yields (Scheme 42). ${ }^{92}$ 


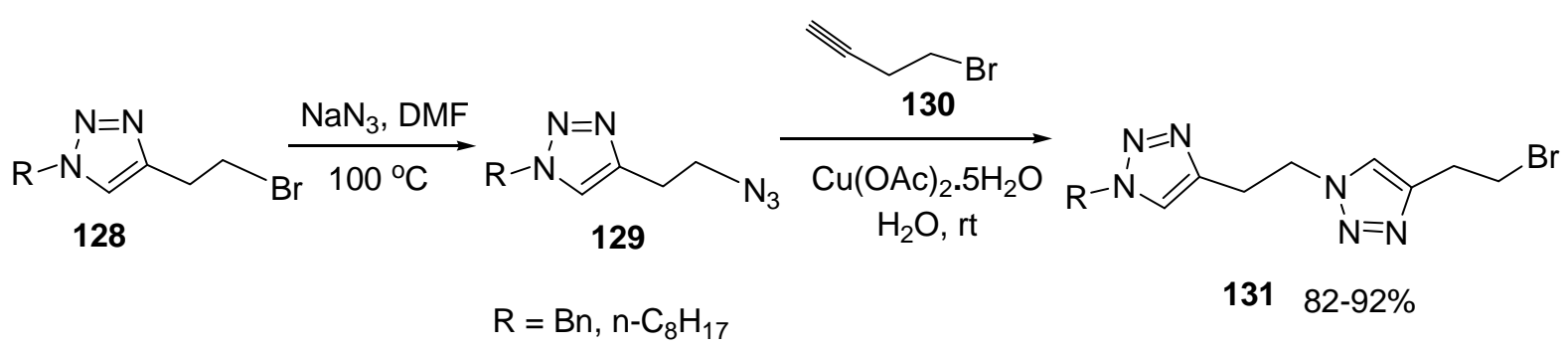

\section{Scheme 42}

Photo irradiation of dibenzo[a,e]cyclooctadiyne (DIBOD) 132 with 350 or $420 \mathrm{~nm}$ fluorescent lamps in the presence of the appropriate azide resulted in the efficient formation of the bis-triazole derivatives 134 via the intermediate 133 (Scheme 43). ${ }^{93,94}$<smiles>[R]c1ccc2c(c1)-c1c(c1=O)-c1ccc([R])cc1-c1c-2c1=O</smiles>

$$
\mathrm{R}=\mathrm{H}, \mathrm{OBu}, \mathrm{O}\left(\mathrm{CH}_{2} \mathrm{CH}_{2} \mathrm{O}\right)_{3} \mathrm{H} \quad \mathrm{R}^{1}=\mathrm{Bu}, \mathrm{Bn}
$$

\section{Scheme 43}

1,8-Diiodonaphthalene 136, prepared from naphthalene-1,8-diamine 135, reacted with 4-aryl-1,2,3triazoles 137 in dry DMSO in the presence of $\mathrm{Cul}$ and $\mathrm{K}_{2} \mathrm{CO}_{3}$ under $\mathrm{N}_{2}$ atmosphere to give the naphthalenebridged bis-triazole derivatives 138 in 42-66\% yields (Scheme 44). ${ }^{95}$ The naphthalene-bridged bis-triazole derivatives $\mathbf{1 3 8}$ were reported to be potential fluorophores for chemical and biological applications and showed high fluorescence efficiency and large Stokes shifts.<smiles>Nc1cccc2cccc(N)c12</smiles>

135

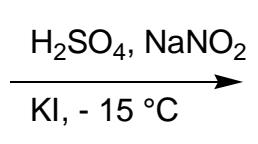

$49 \%$<smiles>Ic1cccc2cccc(I)c12</smiles>

136

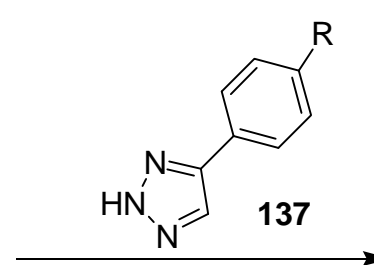

$20 \%$ Cul; $40 \%$ proline 4.0 eqv. $\mathrm{K}_{2} \mathrm{CO}_{3}$, DMSO $120^{\circ} \mathrm{C}$

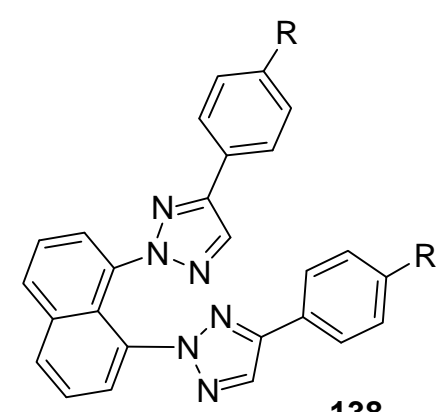

138

$\mathrm{R}=\mathrm{H}, \mathrm{Cl}, \mathrm{OMe}, \mathrm{CO}_{2} \mathrm{Et}, \mathrm{CN}$

\section{Scheme 44}

The bis(1,2,3-triazole) 140, was synthesized in 83\% from $\mathrm{N}$-propargyl-5-phenyltriazole 139 with tosyl azide in the presence of copper(I) thiophene-2-carboxylate (CUTc) catalyst in dry toluene under $\mathrm{N}_{2}$ atmosphere. Treatment of $\mathbf{1 4 0}$ with $\mathrm{Rh}(\mathrm{II})$ catalyst led to selective decomposition of the 1,4-disubstituted 
1,2,3-triazole core, leading to a 3,4-fused dihydroindole 141 in 76\% via intramolecular [3+2]-annulation reaction. Further treatment of 141 with $\mathrm{MnO}_{2}$ at $80{ }^{\circ} \mathrm{C}$ afforded fused indole of bis(1,2,3-triazole) 142 in good yield (Scheme 45). ${ }^{96}$

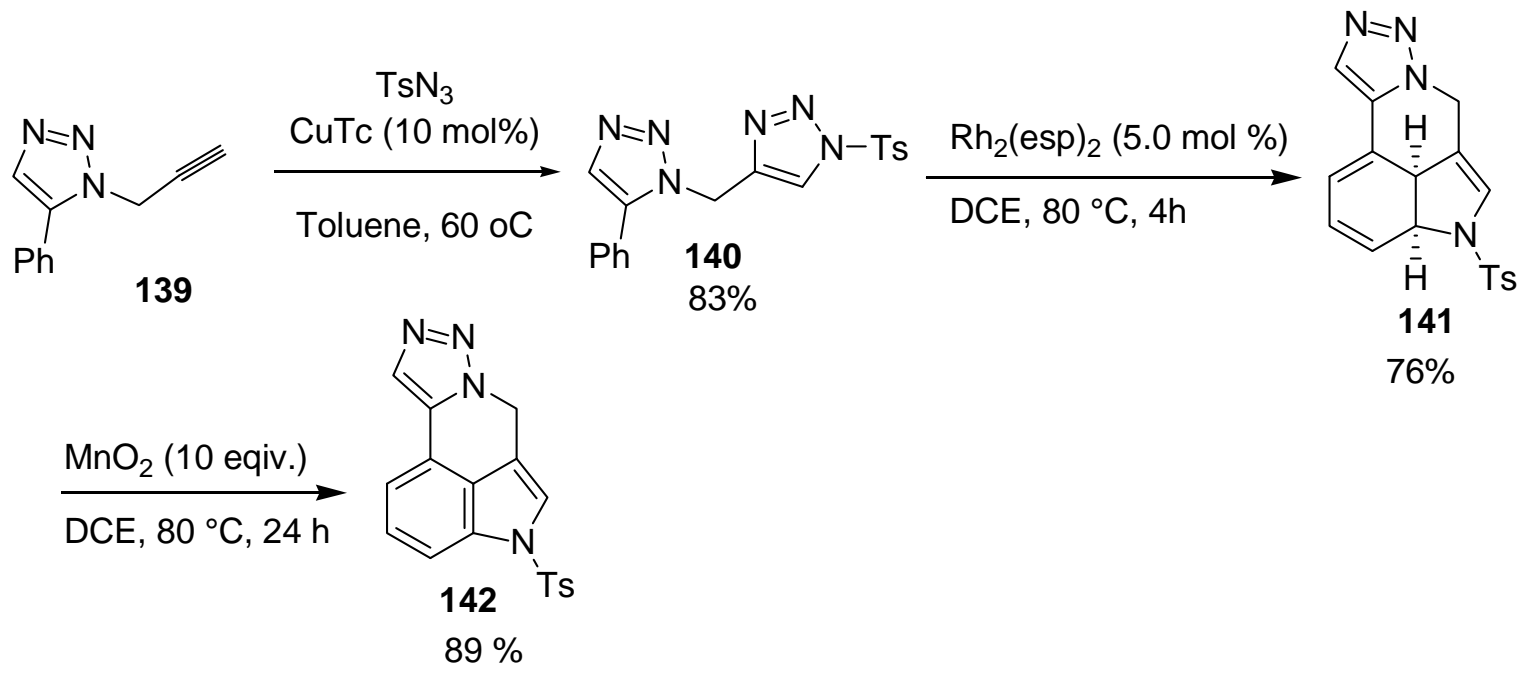

\section{Scheme 45}

Synthesis of the bis-1,2,3-triazole derivatives 144 was conducted starting from a azido-glycoside derivative 143 using Cul-catalyst under microwave irradiation condition. The azide $\mathbf{1 4 3}$ was treated with different terminal alkynes 5 using PMDETA ( N,N,N,N,N-pentamethyldiethylenetriamine) as the base in THF (Scheme 46). ${ }^{97}$

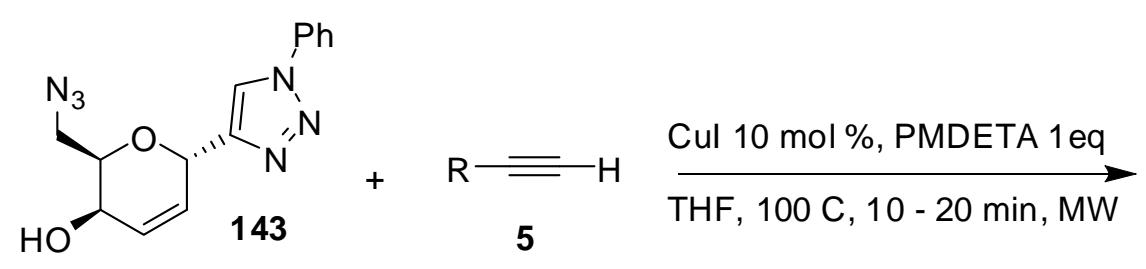

$\mathrm{R}=\mathrm{Ph}$, subs. ph, aryl, cyclopropyl, n-butyl

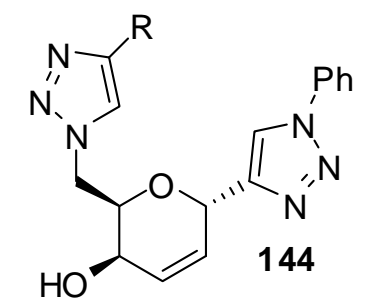

$70-96 \%$

\section{Scheme 46}

Symmetrically substituted bis(1,2,3-triazoles) 146 having butyl or phenyl spacer groups were synthesized in high yields from reaction of the corresponding dialkynes 145 and benzyl azide using copper(I) oxide nanoparticles $\left(\mathrm{Cu}_{2} \mathrm{ONP}\right)$ in glycerol (Scheme 47). ${ }^{98}$
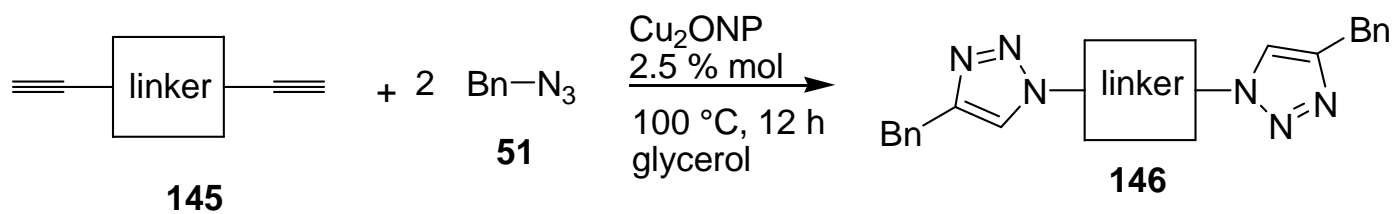

$$
\begin{array}{ll}
\text { linker }\left(\mathrm{CH}_{2}\right)_{4} & 97 \% \\
\text { linker } \mathrm{C}_{6} \mathrm{H}_{4} & 94 \%
\end{array}
$$


The copper-catalyzed coupling bis-alkynes 147 with various organic azides $\mathbf{5 1}$ afforded the corresponding bis(1,2,3-triazole) derivatives 149 through 148 using the polymer-supported catalyst Amberlyst A-21•Cul in DCM at room temperature (Scheme 48 ). ${ }^{99}$ Some of the bis-triazole products 149 showed noteworthy activity against B16 melanoma included in the range 1-20 $\mu \mathrm{M}$.

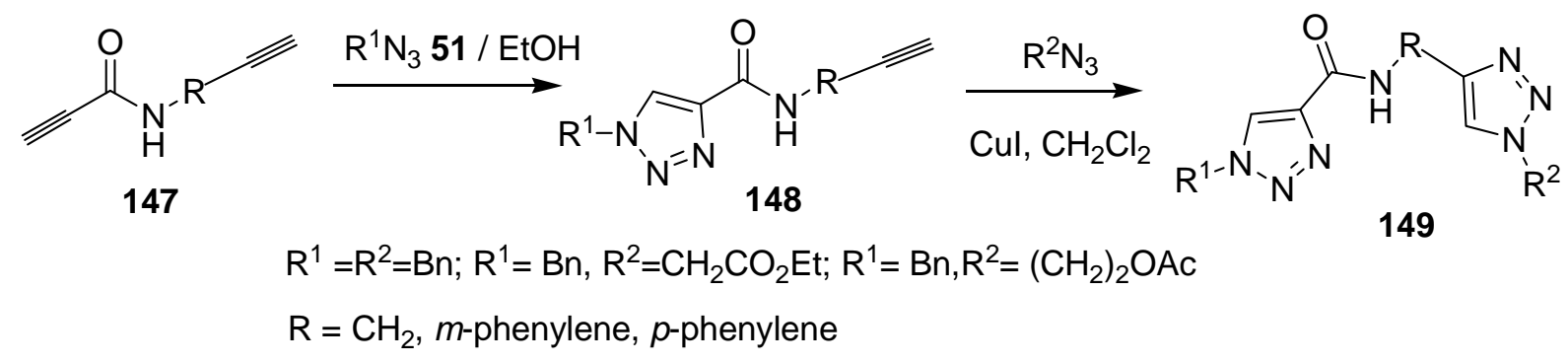

\section{Scheme 48}

One-pot three-component coupling reactions of 150 consisted by double [3+2] reactions followed by substitutions with allylamine, as nucleophile, successfully afforded the bis(1,2,3-triazole) derivative 151 in moderate yield (Scheme 49). ${ }^{100}$

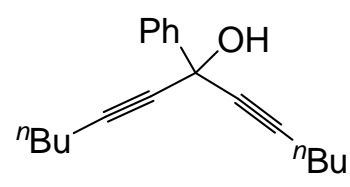

150
1) 1.2 eq $\mathrm{BF}_{3} . \mathrm{OEt}_{2}$, 3 eq. $\mathrm{BnN}_{3}, \mathrm{DCM},-60^{\circ} \mathrm{C}$

2) 3 eq. allylamine, rt

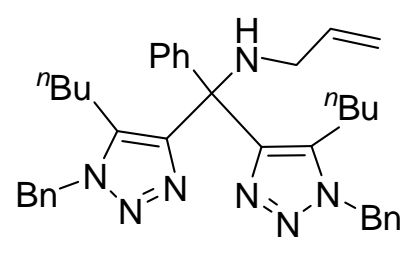

$15148 \%$

\section{Scheme 49}

Thermally driven [3+2] cycloadditions of internal bis-ynamides 152-154 with benzyl azide led to the formation of the bis(1,2,3-triazole) derivatives 155-157 in moderate yields (Scheme 50). ${ }^{101}$

The bis-1,2,3-triazolyl benzothiadiazole derivative 160 was synthesized by ruthenium-catalyzed azide-alkyne cycloaddition between the benzothiadiazole bis-alkyne $\mathbf{1 5 8}$ and azido alanine $\mathbf{1 5 9}$ in 52\% yield as shown in Scheme 51. Photophysical studies demonstrated the crucial role of the prepared bistriazole $\mathbf{1 6 0}$ in the design of new fluorescent chemosensors. ${ }^{102}$

The reaction of 1,4-bis(azidomethyl)benzene 161 with 2 equiv. of ethyl 4-anilino-4-oxo-2-butynoate 162 in toluene under microwave irradiation furnished the mixed regioisomeric bis(1,2,3-triazole) derivatives 163 in $65 \%$ yield (Scheme 52). ${ }^{103}$ 
<smiles>[R]C1OC(=O)CN1C#CCCCCC#CN1C(=O)OC[C@H]1[R]</smiles>

152

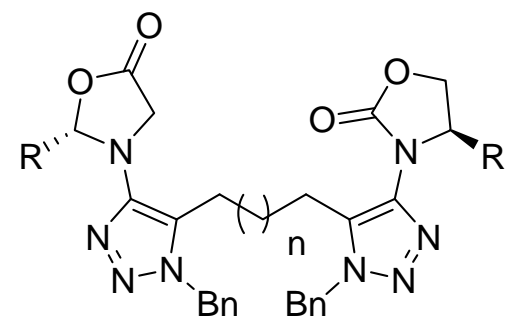

$155 \mathrm{R}=\mathrm{Ph} 41 \%$

$\mathrm{R}=\mathrm{Bn} 35 \%$

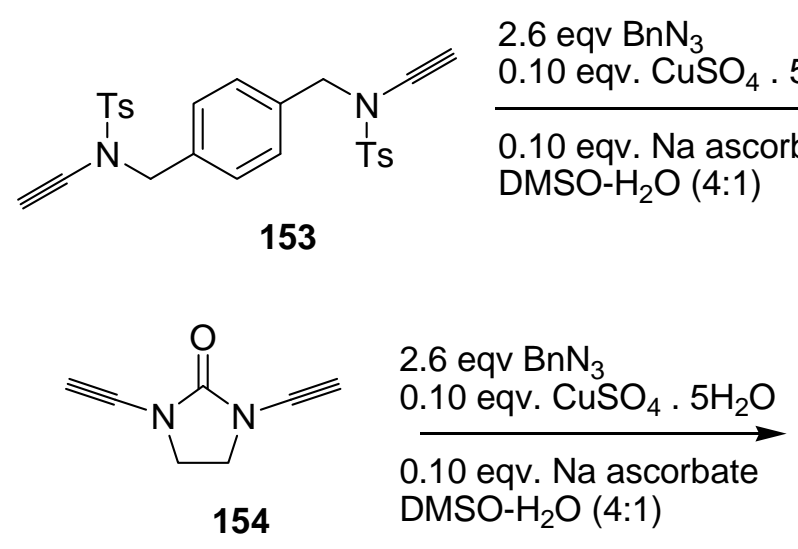<smiles>[3H]N(Cc1ccc(CN([Te])c2cn(Cc3ccccc3)nn2)cc1)c1cn(Cc2ccccc2)nn1</smiles>

$15644 \%$<smiles>O=C1N(c2cn(Cc3ccccc3)nn2)CCN1c1cn(Cc2ccccc2)nn1</smiles>

$15758 \%$

\section{Scheme 50}

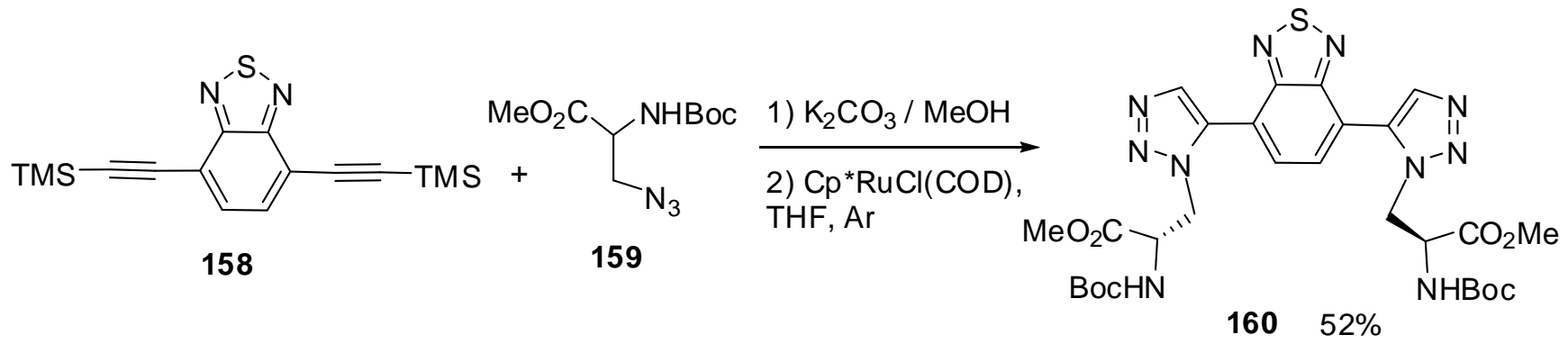

\section{Scheme 51}

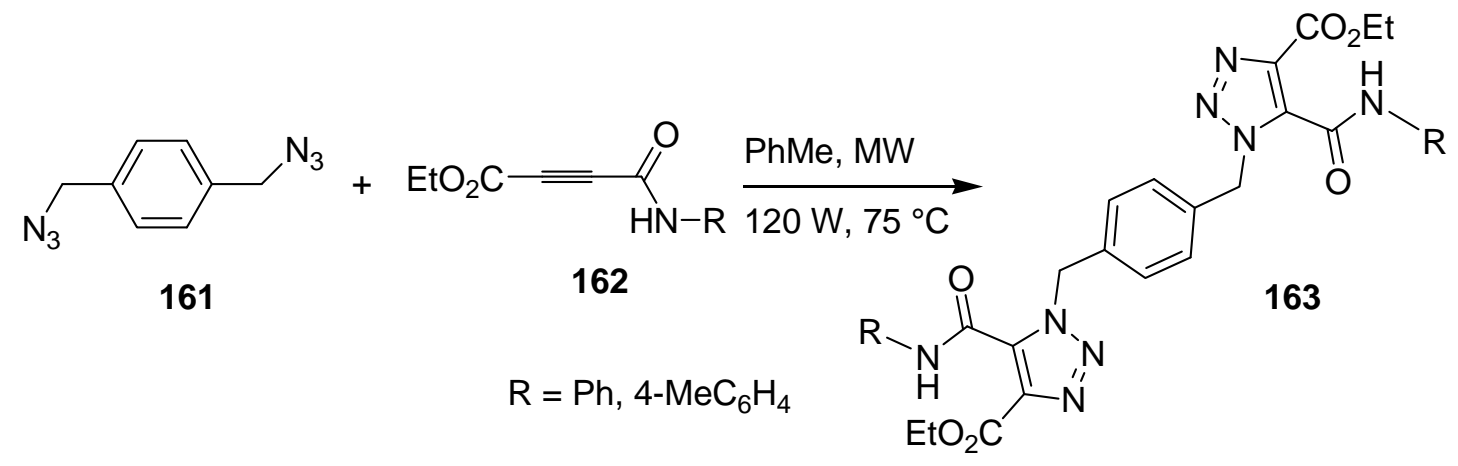

\section{Scheme 52}


Reaction of 1,2-, 1,3- and 1,4-bis(azidomethyl)benzenes 164 with acetylenedicarboxylate esters 165 afforded the corresponding bis(1,2,3-triazole) derivatives 166 (Scheme 53). ${ }^{104}$

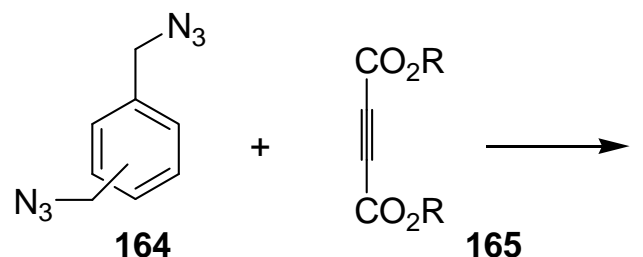

position of triazolylmethyl $=2,3,4$

$$
\mathrm{R}=\mathrm{Me}, \mathrm{Et}, \mathrm{CMe}_{3}
$$

\section{Scheme 53}

Click reaction of the sugar azides $\mathbf{5 1}$ with chalcogeno bis-propargylated catechols and resorcinol derivatives 170 and 174, [prepared by reaction of 167 or 172, with propargyl bromide to afford 168 or 173 which then reacted with methyl ketones 169] using tetrahydrofuran and water as solvent resulted in the formation of the sugar-chalcone based bis-triazole derivatives 171 and 175 in high yields (Scheme 54). ${ }^{105}$
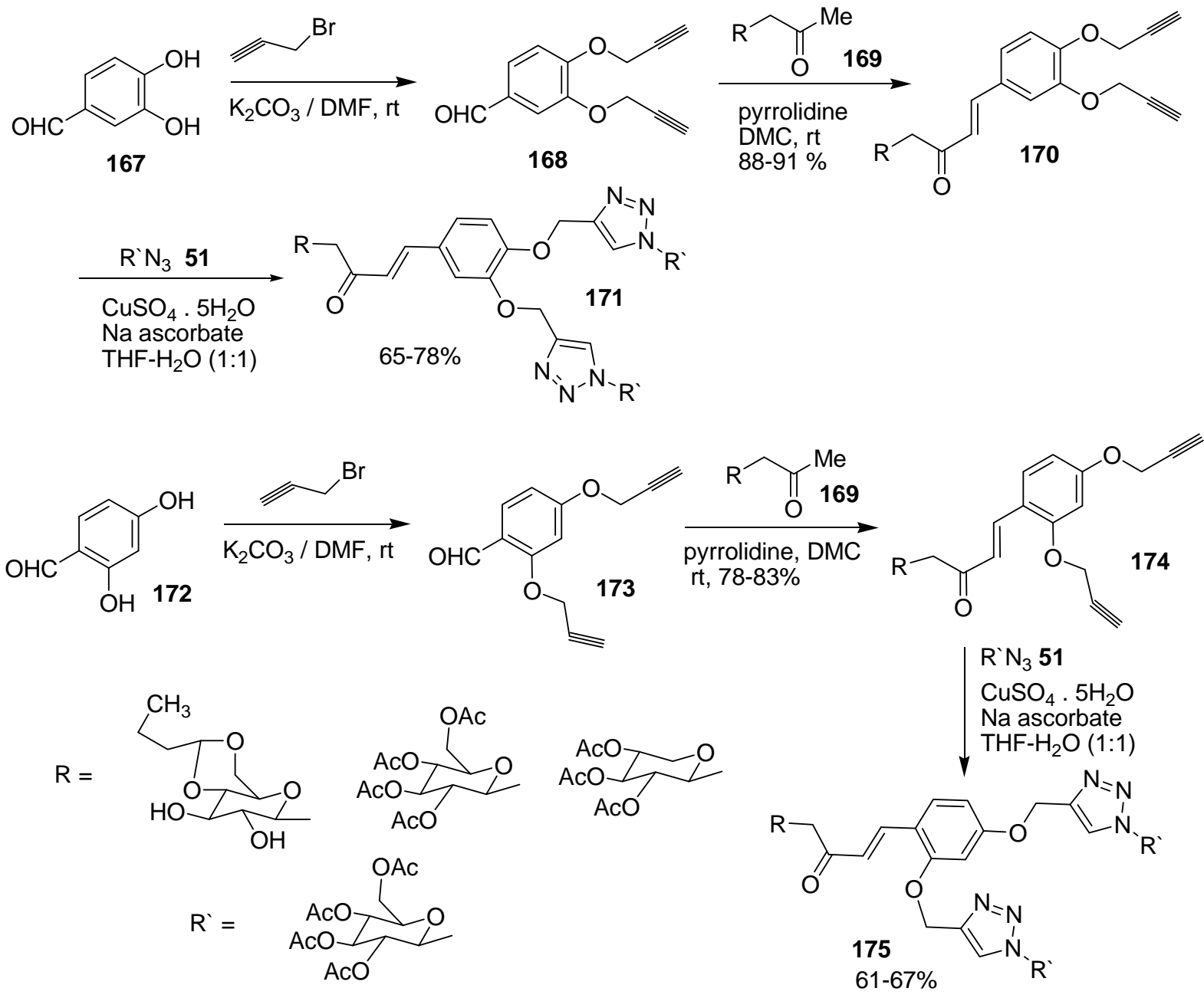

\section{Scheme 54}


Synthesis of bis-1,2,3-triazoles 177 via $\mathrm{Cu}(\mathrm{I})$-catalyzed click reaction of aryl azides and 1,3-bis(prop-2-yn1-yloxy)benzene 176. The latter were synthesized from the reaction of resorcinol with propargyl bromide in the presence of potassium carbonate (Scheme 55). ${ }^{106}$

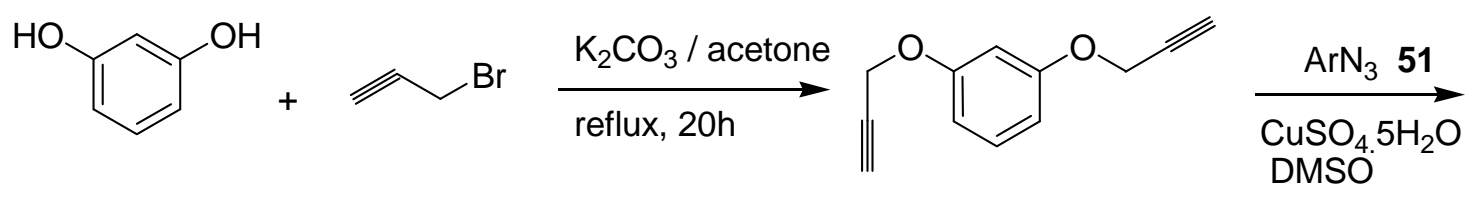

176

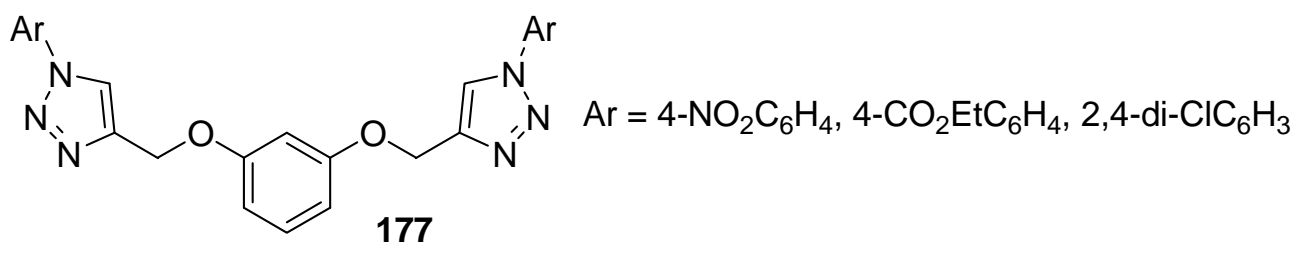

\section{Scheme 55}

Copper(I)-catalyzed click reaction of the bis-alkyne derivatives of catechol 178 or 6,7-dihydroxycoumarin 181 with the azide esters 179 yielded the corresponding bis-1,2,3-triazole derivatives 180 and 182 respectively in high yields (Scheme 56). ${ }^{107}$

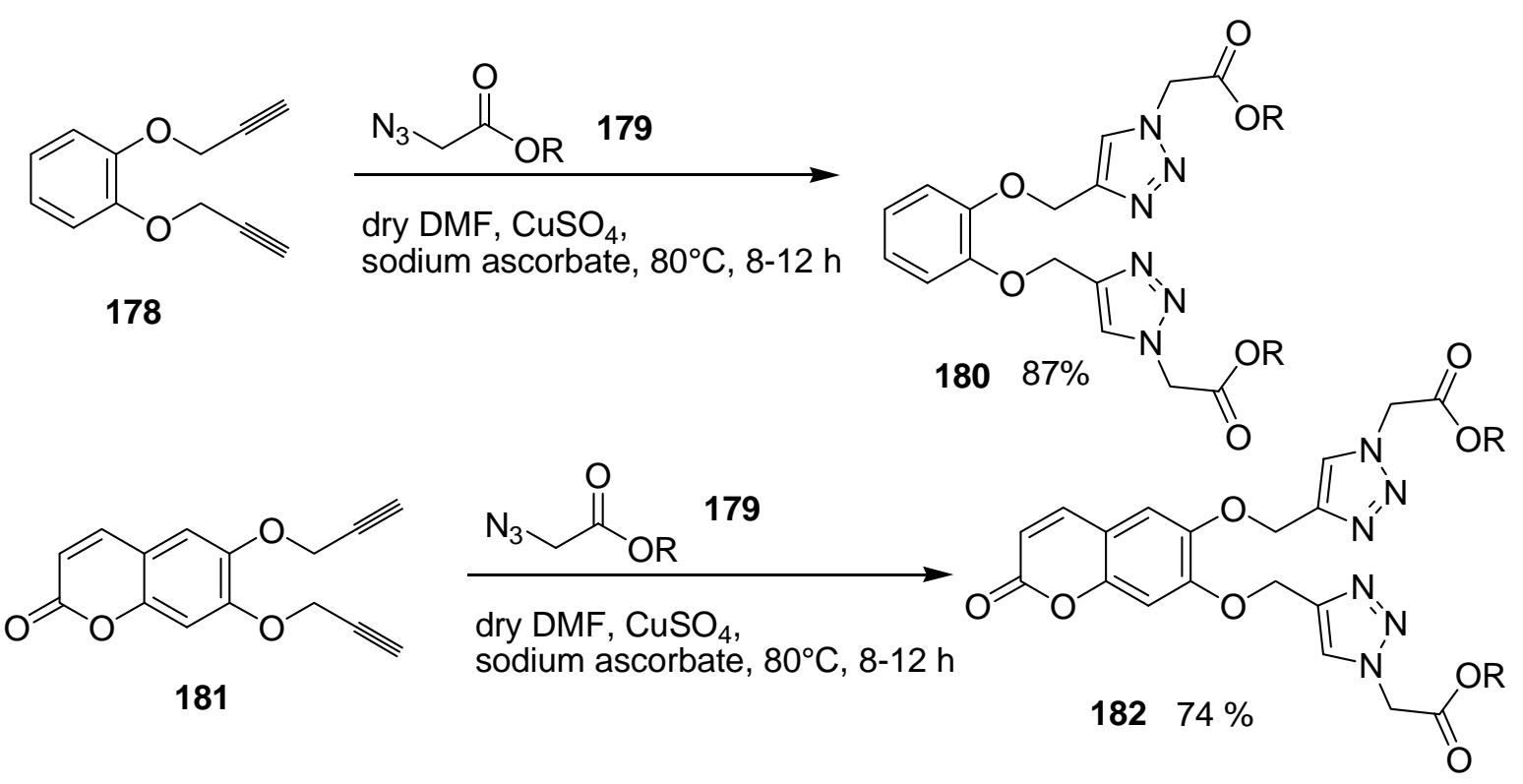

\section{Scheme 56}

1,2,5,6-Di-O-isopropylidene-D-mannitol 183 reacted with propargyl bromide in $\mathrm{NaOH}$ and DMF solvent to give the bis-alkyne 184. The $\mathrm{Cu}(\mathrm{I})$-catalyzed 1,3-dipolar cycloaddition of the bis-alkyne 185 with alkyl azides 51 in DMSO at $50{ }^{\circ} \mathrm{C}$ gave the corresponding bis-triazoles 186 in quantitative yields (Scheme 57). ${ }^{108}$ 

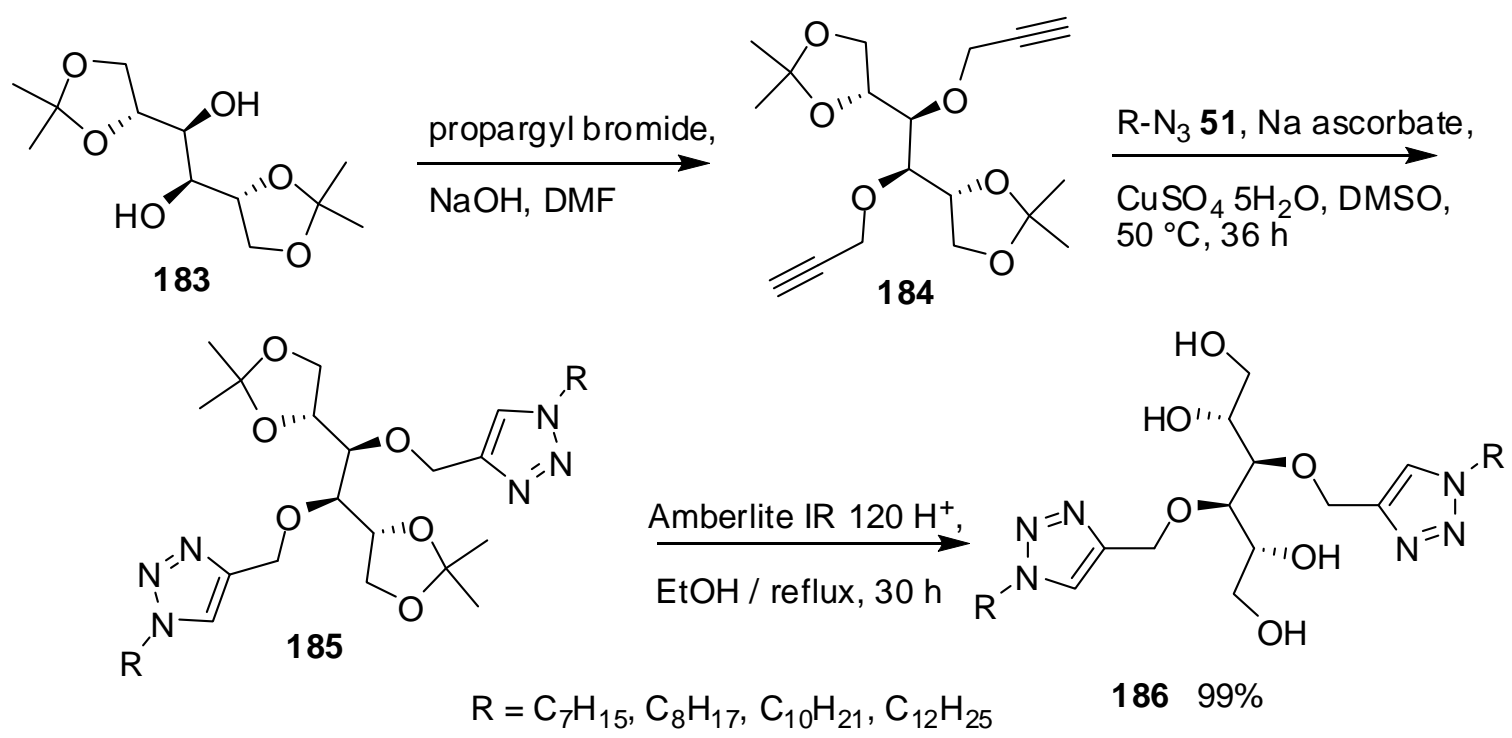

\section{Scheme 57}

The "click" reaction of diazeniumdiolate prodrugs having terminal alkyne groups $\mathbf{1 8 8}$ with the bis-azide 187 was performed using $\mathrm{CuSO}_{4} / \mathrm{Na}$-ascorbate in THF/water. The reaction proceeded quickly (15-45 min) and gave a mixture of two products. The major product was in each case the bis-triazole derivative 189 and the minor product was 5,5'-triazolo-triazole 190. The use of Cul and diisopropylethylamine (DIPEA) as base predominantly gave the cycloaddition/oxidative coupling products; 5,5'-triazolo-triazole 189 as major products (Scheme 58). ${ }^{109}$ The products were reported to have potential biological applications as NO-donors.
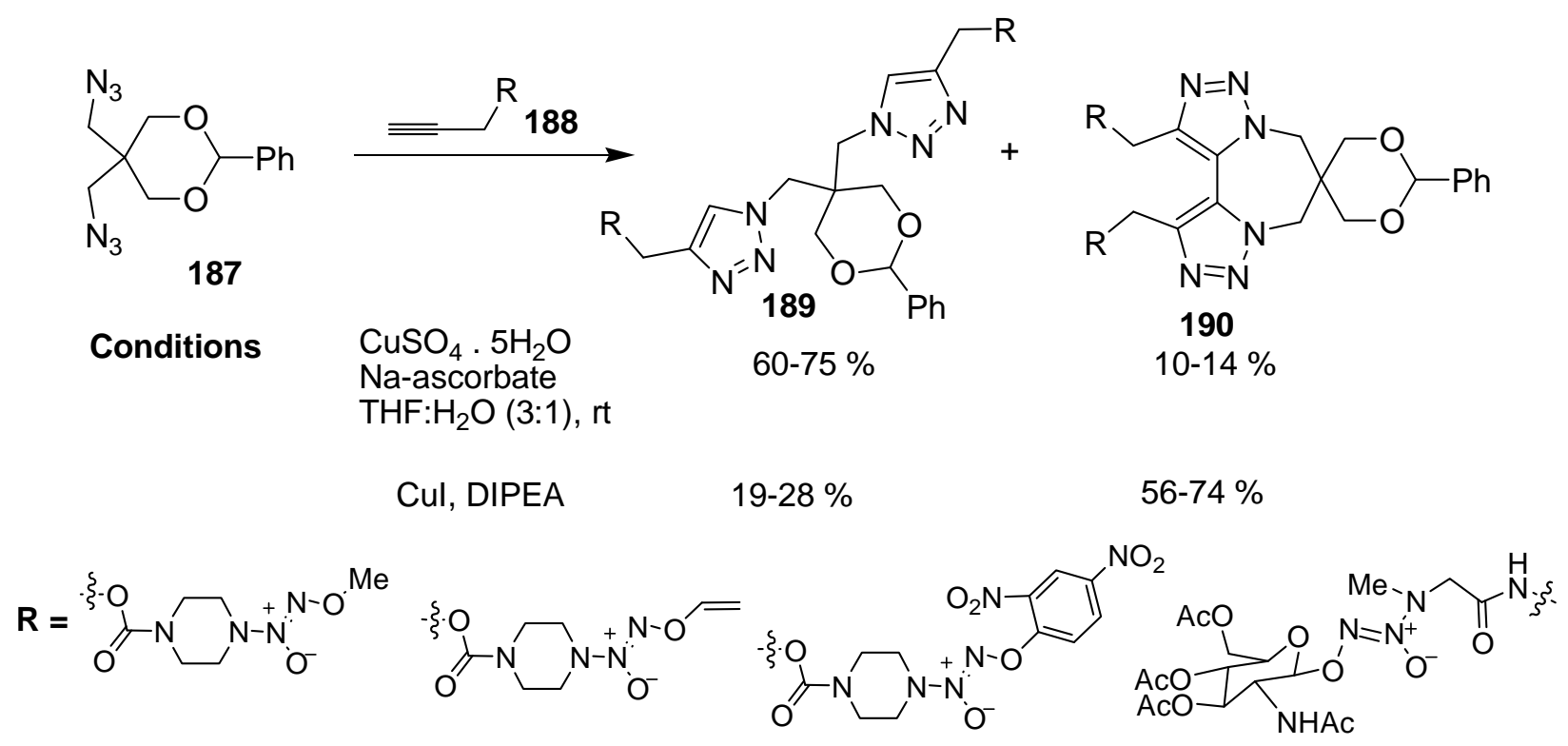

\section{Scheme 58}

Synthesis of the bis-triazolyl ethisterone glycoconjugates 195 was reported using CuAAC reaction condition. At first, the sugar based triazolyl azido-alcohols 195 were synthesized via one pot click reaction of glycosyl alkynes 193 with epichlorohydrin 192 in aqueous medium. Treatment of the triazolyl azido-alcohols 193 with the naturally occurring steroid alkyne (ethisterone) 194 yielded the bis-triazolyl ethisterone 
glycoconjugates 195 regioselectively in good yields (Scheme 59). The products 195 were of potential application in androgen receptor pharmacology and chemical biology. ${ }^{110}$

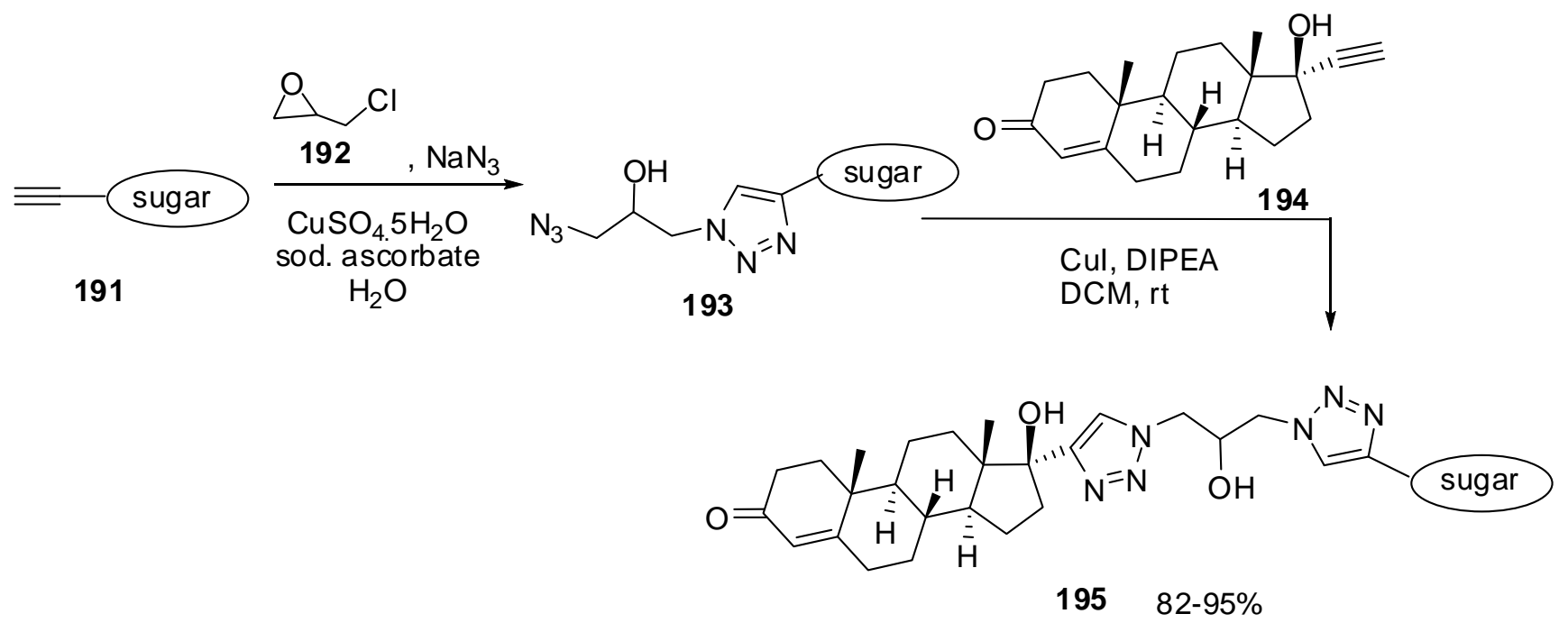

\section{Scheme 59}

\subsection{Bis-(1,2,4-triazoles)}

Reaction of arylaminosulfonylacetic acid hydrazide 196 with sulfonyldiacetic acid 197 in the presence of $\mathrm{POCl}_{3}$ resulted in the formation of bis(1,3,4-oxadiazole) derivatives 198. Treatment of the latter compounds with hydrazine hydrate in $n$-butanol gave the bis(1,3,4-triazole) derivatives 199 (Scheme 60). ${ }^{111}$ Compounds 199 exhibited good antioxidant activity using DPPH, nitric oxide (NO), and hydrogen peroxide $\left(\mathrm{H}_{2} \mathrm{O}_{2}\right)$ methods at 50,75 , and $100 \mu \mathrm{M}$ concentration.

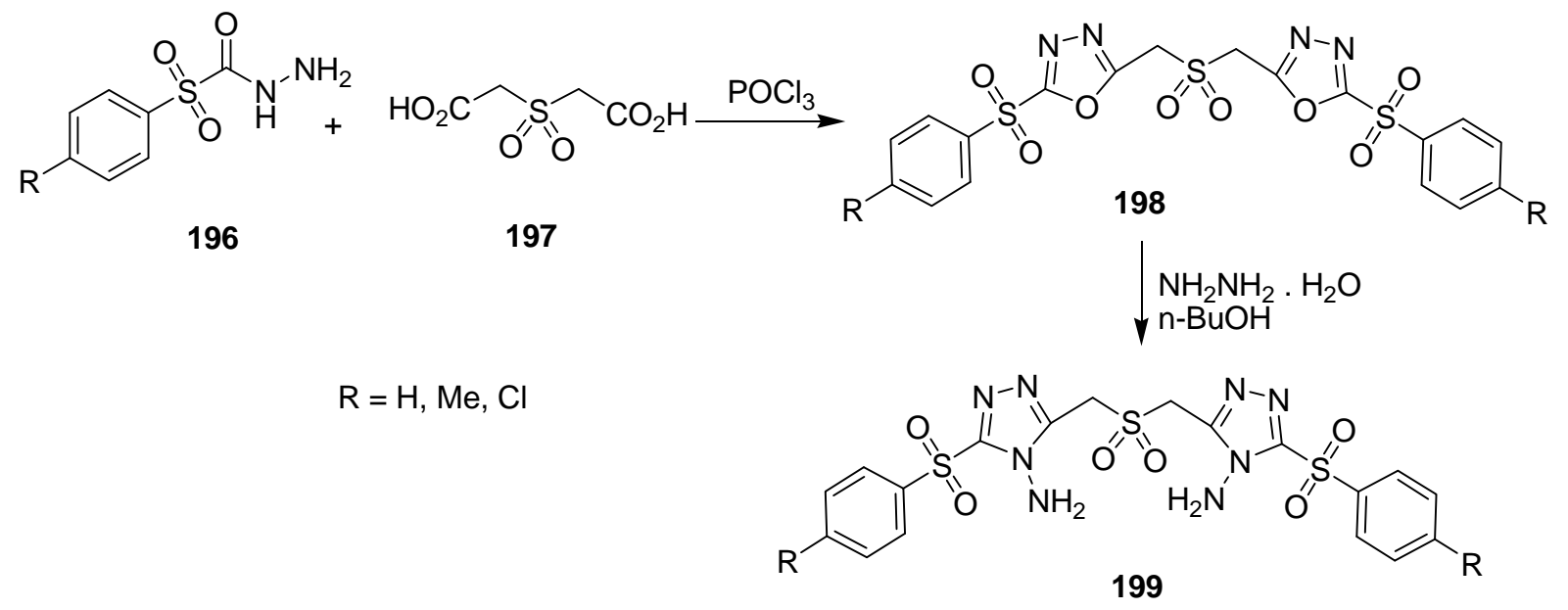

\section{Scheme 60}

The bis(1,2,4-triazole) derivative 202 was synthesized in $42 \%$ yield from the reaction of 2-cyano-3methylthio-3-phenylaminoacrylonitrile 201 with the bis-hydrazonoyl halide 200 in refluxing DMF/EtOH in the presence of triethylamine (Scheme 61). ${ }^{112}$ 
<smiles>Cl/C(=N\Nc1ccccc1)c1ccc(/N=C/c2ccccc2)cc1</smiles>

200<smiles>C[AsH2]C(Nc1ccccc1)=C(C#N)C#N</smiles>

201<smiles>N#CC(C#N)=C1N(c2ccccc2)N=C(c2ccc(C3=NN(c4ccccc4)C(=C(C#N)C#N)N3c3ccccc3)cc2)N1c1ccccc1</smiles>

$42 \% \quad 202$

\section{Scheme 61}

The reaction of 4-amino-1,2,4-triazole $\mathbf{7 4}$ with sodium dichloroisocyanurate (SDCI) afforded the bis(1,2,4-triazole) derivaive 203 in 90\% yield. Increasing the molar ratio of SDCl to 4-amino-1,2,4-triazole, the chlorinated bis(1,2,4-triazole) 204 was formed in 45\% yield (Scheme 62). ${ }^{113}$

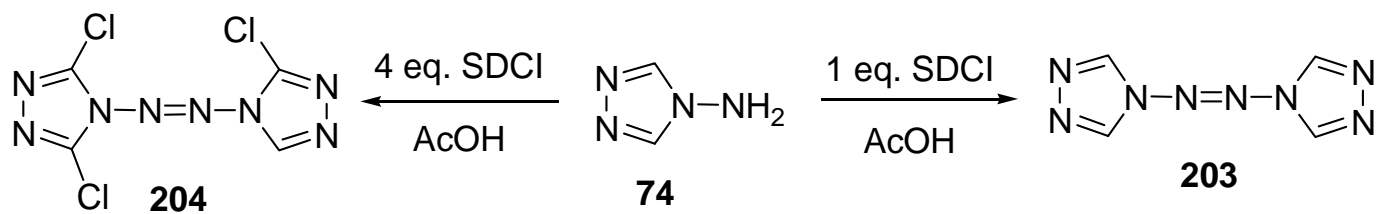

\section{Scheme 62}

Reaction of the amine bis-bromide compounds 205 reacted with $1 \mathrm{H}-1,2,4$-triazole in the presence of potassium carbonate in acetonitrile at $40-70{ }^{\circ} \mathrm{C}$ to give the corresponding amine bis(1,2,4-triazole) derivatives 206 in 67-75\% yields (Scheme 63). ${ }^{114}$ The obtained bis-triazoles 206 exhibited more potent antifungal activity than the clinically prevalent antifungal drug Fluconazole against $C$. albicans with MIC value of $0.25 \mathrm{mg} / \mathrm{mL}$.

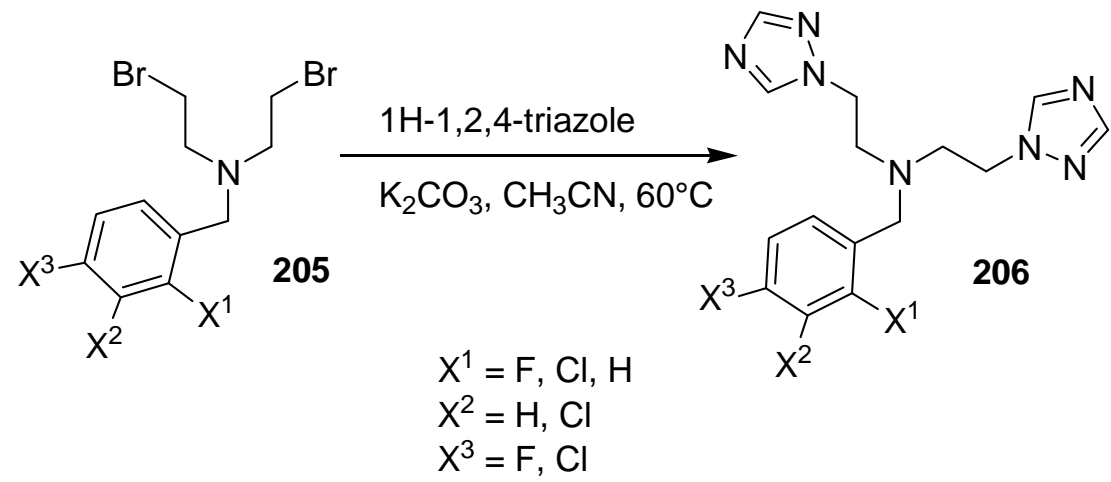

\section{Scheme 63}

Reaction of terephthalic acid bis-hydrazide $\mathbf{2 0 7}$ with aryl iso(thio)cyanate in DMF in the presence of sodium hydride followed by treatment with concentrated $\mathrm{HCl}$ afforded the corresponding (thio)semicarbazide 208. The bis-(thio)semicarbazides on treatment with sodium hydroxide led to the formation of the bis(1,2,4triazole) derivatives 209 in 64-69\% yields (Scheme 64). ${ }^{115}$ 


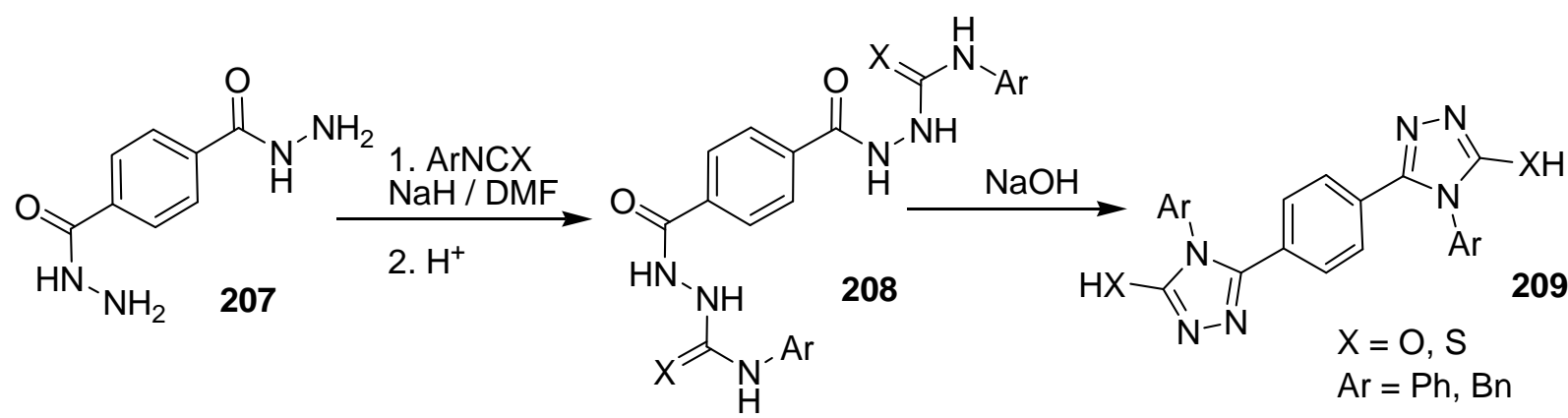

\section{Scheme 64}

Fusion of 1,4-bis-phenoxyacetic acids $\mathbf{2 1 1}$, prepared by heating of $\mathbf{2 1 0}$ with chloroacetic acid and sodium hydroxide in water, with thiocarbazide 92 afforded 1,4-bis-(1,2,4-triazol-3-ylmethoxy)phenylenes 212 in a one pot reaction in good yields (Scheme 65). ${ }^{116}$<smiles>[R20]c1cc(O)c([R])cc1O</smiles><smiles>[R11]c1cc(OCC(=O)O)c([R])cc1OCC(=O)O</smiles><smiles>NNC(=S)NN</smiles><smiles>[R]c1cc(OCc2nnc(S)n2N)c([R])cc1OCc1nnc(S)n1N</smiles>

\section{Scheme 65}

\section{References}

1. Ferreira, S. B.; Sodero, A. C. R.; Cardoso, M. F. C.; Lima, E. S.; Kaiser, C. R.; Silva, F. P.; Ferreira, V. F. J. Med. Chem. 2010, 53, 2364-2375. https://doi.org/10.1021/im901265h

2. Cho, J. H.; Bernard, D. L.; Sidwell, R. W.; Kern, E. R.; Chu, C. K. J. Med. Chem. 2006, 49, 1140-1148. https://doi.org/10.1021/im0509750

3. Giffin, M. J.; Heaslet, H.; Brik, A.; Lin, Y.-C.; Cauvi, G.; Wong, C.-H.; McRee, D. E.; Elder, J. H.; Stout, C. D.; Torbett, B. E. J. Med. Chem. 2008, 51, 6263-6270.

https://doi.org/10.1021/jm800149m

4. Reck, F.; Zhou, F.; Girardot, M.; Kern, G.; Eyermann, C. J.; Hales, N. J.; Ramsay, R. R.; Gravestock, M. B. J. Med. Chem. 2005, 48, 499-506. https://doi.org/10.1021/jm0400810

5. Foroumadi, A.; Mansouri, S.; Kiani, Z.; Rahmani, A. Eur. J. Med. Chem. 2003, 38, 851-854. 
https://doi.org/10.1016/S0223-5234(03)00148-X

6. Ram, V. J.; Mishra, L.; Pandey, N. H.; Kushwaha, D. S.; Pieter, L. A. C.; Vlietinck, A. J. J. Heterocycl. Chem. 1990, 27, 351-355.

https://doi.org/10.1002/jhet.5570270245

7. Ergenc, N.; Ilhan, E. Pharmazie 1992, 47, 59-60.

8. Kalyoncuoglu, N.; Rollas, S.; Ur-Altiner, D.S.; Yegenoglu, Y. Anğ O. Pharmazie 1992, 47, 796-97.

9. Rollas, S.; Kalyoncuoglu, N.; Ur-Altiner, D. S.; Yegenoglu, Y. Pharmazie 1993, 48, 308-309.

10. Nagesh, H.N.; Naidu, K.M.; Rao, D.H.; Sridevi, J.P.; Sriram, D.; Yogeeswari, P.; Gowri, K.V.; Sekhar C. Bioorg. Med. Chem. Lett. 2013, 23, 6805-6810.

https://doi.org/10.1016/i.bmcl.2013.10.016

11. Sheng, C.; Zhang, W. Curr. Med. Chem. 2011, 18, 733-766.

https://doi.org/10.2174/092986711794480113

12. Baxter, C. A.; Cleator, E.; Brands, K. M. J.; Edwards, J. S.; Reamer, R. A.; Sheen, F. J.; Stewart, G. W.; Strotman, N. A.; Wallace, D. J. Org. Process Res. Dev. 2011, 15, 367-375.

https://doi.org/10.1021/op1002853

13. E.-V'azquez, A.; R.-G'omez, F. J.; G.-Olvera, R.; A.-Beltran, D.; M.-Espinosa, D.; N.-Silva, G. E. RSC Adv. 2016, 18, 72885-72896.

14. E.-V'azquez, A.; N.-Silva, G. E.; G.-Olvera, R.; A.-Beltran, D.; H.-Hern'andez, H.; R.-Romo, M. A.; P.Pardav'e, M. E. Mater. Chem. Phys. 2014, 145, 407-417.

15. Kudari, S. M.; Beede, S. M.; Munera, W. Asian J. Chem. 1997, 9, 20-26.

16. Al-Soud, Y. A.; Al-Dweri, M. N.; Al-Masoudi, N. A. I/ Farmaco 2004, 59, 775. https://doi.org/10.1016/j.farmac.2004.05.006

17. Wang, Y.; Zhou, C.H. Scientia Sinica Chemica 2011, 41, 1429-1456. https://doi.org/10.1360/032010-843

18. Shi, Y.; Zhou, C.H. Bioorg. Med. Chem. Lett. 2011, 21, 956-960. https://doi.org/10.1016/i.bmcl.2010.12.059

19. Shi, Y.; Zhou, C.H.; Zhou, X.D.; Geng, R.X.; Ji, Q.G. Acta Pharm. Sinica 2011, 46, 798-810.

20. Xia, Y.; Qu, F. Q.; Peng, L. Mini-Rev. Med. Chem. 2010, 10, 806. https://doi.org/10.2174/138955710791608316

21. Poyatos, M.; McNamara, W.; Incarvito, C.; Clot, E.; Peris, E.; Crabtree, R. H. Organometallics 2008, 27, 2128-2136.

https://doi.org/10.1021/om800021c

22. Hohloch, S.; Suntrup, L.; Sarkar, B. Organometallics 2013, 32, 7376-7385. https://doi.org/10.1021/om4009185

23. Jia, L.-H.; Liu, A.-C.; Wang, B.-W.; Wang, Z.-M.; Gao, S. Polyhedron 2011, 30, 3112-3115. https://doi.org/10.1016/j.poly.2011.02.049

24. Govor, E. V.; Lysenko, A. B.; Rusanov, E. B.; Chernega, A. N.; Krautscheid, H.; Domasevitch, K. V. Z. Anorg. Allg. Chem. 2010, 636, 209-217.

https://doi.org/10.1002/zaac.200900121

25. Habib, H. A.; Sanchiz, J.; Janiak C. Dalton Trans. 2008, 1734. https://doi.org/10.1039/b715812b

26. Garcia, Y.; Bravic, G.; Gieck, C.; Chasseau, D.; Tremel, W.; Gu1tlich, P. Inorg. Chem. 2005, 44, 9723. https://doi.org/10.1021/ic050971I 
27. Huang, Y.-Q.; Zhao, X.-Q.; Shi, W.; Liu, W.-Y.; Chen, Z.-L.; Cheng, P.; Liao, D.-Z.; Yan, S.-P. Cryst. Growth Des. 2008, 8, 3652-3660.

https://doi.org/10.1021/cg8002564

28. Abdel-Wahab, B. F.; Mohamed, H. A.; Farahat, A. A.; Dawood, K. M. Heterocycles 2011, 83, 2731 - 2767. https://doi.org/10.3987/REV-11-717

29. Dawood, K. M.; Elwan, N. M.; Abdel-Wahab, B. F. Arkivoc 2011,(i), 111-195.

http://dx.doi.org/10.3998/ark.5550190.0012.102

30. Abdel-Wahab, B. F.; Dawood, K. M. Arkivoc 2012,(i), 491-545.

http://dx.doi.org/10.3998/ark.5550190.0013.112

31. Dawood, K. M.; Abdel-Gawad, H.; Mohamed, H. A.; Abdel-Wahab, B. F. Heterocycles 2010, 81, 1-55. https://doi.org/10.3987/REV-09-659

32. Dawood, K. M.; Abdel-Wahab, B. F. Arkivoc 2010, 333-389.

http://dx.doi.org/10.3998/ark.5550190.0011.109

33. Dawood, K. M. Expert Opin. Ther. Pat. 2013, 23, 1133-1156.

34. Joyce, A. W. US 1959-811525; Chem. Abstr. 1961, 55, 45899.

35. Li, W.; Xia, Y.; Fan, Z.; Qu, F.; Wu, Q.; Peng, L. Tetrahedron Lett. 2008, 49, 2804-2809. https://doi.org/10.1016/i.tetlet.2008.02.139

36. Xia, Y.; Li, W.; Qu, F. Q.; Fan, Z. J.; Liu, X. F.; Berro, C.; Rauzy, E.; Peng, L. Org. Biomol. Chem. 2007, 5, 1695-1701.

https://doi.org/10.1039/b703420b

37. Aouial, M.; Bernardini, A.; Viallefont, P. J. Heterocycl. Chem. 1977, 14, 397-400.

https://doi.org/10.1002/jhet.5570140307

38. Tang, Y.; He, C.; Mitchell, L. A.; Parrishb, D. A.; Shreeve, J. M. J. Mater. Chem. A 2016, 4, 3879-3885. https://doi.org/10.1039/C5TA09803C

39. Xia, Y.; Fan, Z.; Yao, J.; Liao, Q.; Li, W.; Qu, F.; Peng, L. Bioorg. Med. Chem. Lett. 2006, 16, 2693-2698. https://doi.org/10.1016/i.bmcl.2006.02.023

40. Xia, Y.; Qu, F.; Li, W.; Wu, Q.; Peng, L. Heterocycles 2005, 65, 345-352.

https://doi.org/10.3987/COM-04-10202

41. Pevzner, M. S.; Kulibabina, T. N.; Malinina, L. A. Chem. Heterocycl. Cpds. 1979, 15, 456-458. https://doi.org/10.1007/BF00471787

42. Shawali, A. S.; Farag, A. M.; Albar, H. A.; Dawood, K. M. Tetrahedron 1993, 49, 2761-2766. https://doi.org/10.1016/S0040-4020(01)86352-3

43. Farag, A. M.; Shawali, A. S.; Abed, N. M.; Dawood, K. M. Gazz. Chim. Ital. 1993, 123, 467-470.

44. Ganapaty, S.; Ramalingam, P.; Babu, Rao C. H. J. Pharm. Res. 2007, 6, 10-12.

45. Dobosz, M.; Rekas, J. Acta Pol. Pharm. 1992, 49, 51-54.

46. Shawali, A. S.; Sayed, A. R.; Zayed, M. M. J. Sulfur Chem. 2011, 32, 311-314. https://doi.org/10.1080/17415993.2011.586456

47. Zhu, J.; Li, K.; Zhang, C.; Wang, J.; Chen, S. J. Mol. Struct. 2017, 1145, 285-291. https://doi.org/10.1016/i.molstruc.2017.05.106

48. Centore, R.; Carella, A.; Fusco, S. Struct. Chem. 2011, 22, 1095-1103. https://doi.org/10.1007/s11224-011-9805-0

49. Klapoetke, T. M.; Schmid, P.C.; Schnell, S.; Stierstorfer, J. J. Mater. Chem. A 2015, 3, 2658-2668. https://doi.org/10.1039/C4TA05964F

50. Sangshetti, J. N.; Lokwani, D. K.; Sarkate, A. P.; Shinde, D. B. Chem. Biol. Drug Design 2011, 78, 800-809. 
https://doi.org/10.1111/i.1747-0285.2011.01178.x

51. Xu, L.; Zhang, X.-Ch.; Liu, W.-G.; Liu, B. J. Struct. Chem. 2012, 53, 179-183.

https://doi.org/10.1134/S0022476612010246

52. Mattiuzzi, A.; Jabin, I.; Moucheron, C.; Mesmaeker, A. K. Dalton Trans. 2011, 40, 7395-7402. https://doi.org/10.1039/c1dt10235d

53. Welby, C. E.; Grkinic, S.; Zahid, A.; Uppal, B. S.; Gibson, E. A.; Ricea, C. R.; Elliott P. I. P. Dalton Trans. 2012, 41, 7637- 7646.

https://doi.org/10.1039/c2dt30510k

54. Fletcher, J. T.; Bumgarner, B. J.; Engels, N. D.; Skoglund, D. A. Organometallics 2008, 27, 5430-5433. https://doi.org/10.1021/om800768k

55. Hohloch, S.; Kaiser, S.; Duecker, F. L.; Bolje, A.; Maity, R.; Kosmrlj, J.; Sarkar, B. Dalton Trans. 2015, 44, 686-693. https://doi.org/10.1039/C4DT02879A

56. Suntrup, L.; Klenk, S.; Klein, J.; Sobottka, S.; Sarkar, B. Inorg. Chem. 2017, 56, 5771-5783. https://doi.org/10.1021/acs.inorgchem.7b00393

57. Guisado-Barrios, G.; Bouffard, J.; Donnadieu, B.; Bertrand, G. Organometallics 2011, 30, 6017-6021. https://doi.org/10.1021/om200844b

58. Boratyński, P. J.; Kowalczyk, R. J. Org. Chem. 2016, 81, 8029-8034. https://doi.org/10.1021/acs.joc.6b01403

59. Norris, W. P.; Finnegan, W. G. J. Org. Chem. 1966, 31, 3292-5. https://doi.org/10.1021/jo01348a043

60. Monkowius, U.; Ritter, S.; Koenig, B.; Zabel, M.; Yersin, H. Eur. J. Inorg. Chem. 2007, 29, 4597-4606. https://doi.org/10.1002/ejic.200700479

61. Fiandanese, V.; Bottalico, D.; Marchese, G.; Punzi, A.; Capuzzolo, F. Tetrahedron 2009, 65, 10573-10580. https://doi.org/10.1016/i.tet.2009.10.078

62. Fiandanese, V.; Maurantonio, S.; Punzi, A.; Rafaschieri, G. G. Org. Biomol. Chem. 2012, 10, $1186-1195$. https://doi.org/10.1039/C10B06701J

63. Alabi, C. A.; Chen, Z.; Yan, Y. S.; Davis, M. E. Chem. Mat. 2009, 21, 4645-4652. https://doi.org/10.1021/cm901772q

64. Chiu, C.-Y.; Chung, J.-H.; Kuo, W.-F.; Yeh, M.-Y. J. Chin. Chem. Soc. 2002, 49, 1003-1014. https://doi.org/10.1002/jccs.200200144

65. Naik, A. D.; Marchand-Brynaert, J.; Garcia, Y. Synthesis 2008, 149-154.

66. Mendoza, J. D.; Castellanos, M. L.; Fayet, J. P.; Vertut, M. C.; Elguero, J. J. Chem. Res. Synop. 1980, 50-51.

67. Li, L.; Chi, Y.; Zhang, X.-Y.; Zhang, G.-Q.; Zhang, Y.; Zhao, T.-X.; Huang, M.; Li, H.-B. Chin. Chem. Lett. 2013, 24, 786-788.

https://doi.org/10.1016/j.cclet.2013.05.010

68. Castellanos, M. L.; Llinas, M.; Bruix, M.; Demendoza, J.; Martin, M. R. J. Chem. Soc. Perkin Trans. 1985, 1209.

69. Farag, A. M.; Dawood, K. M.; Khedr, N. A. J. Chem. Res. 2007, 472-474. https://doi.org/10.3184/030823407X237876

70. Carlsen, P. H. J.; Iversen, E. H.; Samuelsen, E. J.; Helgesson, G.; Jagner, S. Acta Chem. Scand. 1992, 46, 200-4.

https://doi.org/10.3891/acta.chem.scand.46-0200

71. Kamble, R. R.; Sudha, B. S. J. Serb. Chem. Soc. 2006, 71, 331-337. 
https://doi.org/10.2298/JSC0604331K

72. Baryshnikov, A. T.; Erashko, V. I.; Zubanova, N. I.; Ugrak, B. I.; Shevelev, S. A.; Fainsilberg, A. A.; Semenov, V. V. Izv. Akad. Nauk, Seriya Khim. 1992, 2123-2131.

73. Invidiata, F. P.; Aiello, S.; Furno, G.; Aiello, E.; Simoni, D.; Rondanin, R. J. Heterocycl. Chem. 2000, 37, 355361.

https://doi.org/10.1002/ihet.5570370221

74. Aizpurua, J. M.; Sagartzazu-Aizpurua, M.; Azcune, I.; Miranda, J. I.; Monasterio, Z.; Garcia-Lecina, E.; Fratila, R. M. Synthesis 2011, 2737-2742.

https://doi.org/10.1055/s-0030-1260061

75. Wang, M.; Zhu, R.; Fan, Z.; Fu, Y.; Feng, L.; Yao, J.; Maggiani, A.; Xia, Y.; Qu, F.; Peng, L. Bioorg. Med. Chem. Lett. 2011, 21, 354-357.

https://doi.org/10.1016/i.bmcl.2010.10.141

76. Xia, Y.; Wang, M.; Demaria, O.; Tang, J.; Rocchi, P.; Qu, F.; lovanna, J. L.; Alexopoulou, L.; Peng, L. J. Med. Chem. 2012, 55, 5642-5646.

https://doi.org/10.1021/jm300534u

77. Gonzalez, J.; Perez, V. M.; Jimenez, D. O.; Lopez-Valdez, G.; Corona, D.; Cuevas-Yanez, E. Tetrahedron Lett. 2011, 52, 3514-3517.

https://doi.org/10.1016/j.tetlet.2011.05.002

78. Angell, Y.; Burgess, K. Angew. Chem. Int. Ed. 2007, 46, 3649-3651.

https://doi.org/10.1002/anie.200700399

79. Metelkina, E. L.; Novikova, T. A.; Berdonosova, S. N.; Berdonosov, D. Yu. Russ. J. Org. Chem. 2005, 41, 440-443.

https://doi.org/10.1007/s11178-005-0184-0

80. Metelkina, E. L.; Novikova, T. A. Russ. J. Org. Chem. 2004, 40, 1737-1743.

https://doi.org/10.1007/s11178-005-0091-4

81. Metelkina, E. L.; Novikova, T. A.; Berdonosova, S. N.; Berdonosov, D. Yu.; Grineva, V. S. Russ. J. Org. Chem. 2004, 40, 1412-1414.

https://doi.org/10.1007/s11178-005-0033-1

82. Dippold, A. A.; Klapötke, T. M. Chem.-Eur. J. 2012, 18, 16742- 16753.

https://doi.org/10.1002/chem.201202483

83. Dippold, A. A.; Klapötke, T. M.; Winter, N. Eur. J. Inorg. Chem. 2012, 3474-3484.

https://doi.org/10.1002/ejic.201200221

84. Bennion, J. C.; McBain, A.; Son, S. F.; Matzger, A. J. Cryst. Growth Des. 2015, 15, 2545-2549. https://doi.org/10.1021/acs.cgd.5b00336

85. Dippold, A. A.; Klapötke, T. M. J. Am. Chem. Soc. 2013, 135, 9931-9938.

86. Seth, S.; Matzger, A. J. Inorg. Chem. 2017, 56, 561-565.

https://doi.org/10.1021/acs.inorgchem.6b02383

87. Dong, Y.; Peng, P.; Hu, B.; Su, H.; Li, S.; Pang, S. Molecules 2017, 22, 1068.

https://doi.org/10.3390/molecules22071068

88. Chavez, D. E.; Bottaro, J. C.; Petrie, M.; Parrish, D. A. Angew. Chem. Int. Ed. 2015, 54, 12973-12975. https://doi.org/10.1002/anie.201506744

89. Yin, P.; Shreeve, J. M. Angew. Chem. Int. Ed. 2015, 54, 14513-14517. https://doi.org/10.1002/anie.201507456

90. Ma, Q.; Lu, H.; Qu, Y.; Liao, L.; Li, J.; Fan, G.; Chen, Y. Cent. Eur. J. Energ. Mater. 2017, 14, $281-295$. 
https://doi.org/10.22211/cejem/69299

91. Zheng, Z. J.; Wang, D., Xu, Z., Xu, L. W. Beilstein J. Org. Chem. 2015, 11; 2557-2576.

https://doi.org/10.3762/bjoc.11.276

92. Fiandanese, V.; lannone, F.; Marchese, G.; Punzi, A. Tetrahedron 2011, 67, 5254-5260. https://doi.org/10.1016/i.tet.2011.05.040

93. Sutton, D. A.; Popik, V. V. J. Org. Chem. 2016, 81, 8850-8857. https://doi.org/10.1021/acs.joc.6b01545

94. Sutton, A. D.; Yu, S. H.; Steet, R.; Popik, V. V. Chem. Commun. 2016, 52, 553. https://doi.org/10.1039/C5CC08106H

95. Zhang, Y.; Ye, X.; Petersen, J. L.; Li, M.; Shi, X. J. Org. Chem. 2015, 80, 3664-3669. https://doi.org/10.1021/acs.joc.5b00006

96. Jana, S.; Vroemans, R.; Dehaen, W. Adv. Synth. Cat. 2017, 359, 3085-3089. https://doi.org/10.1002/adsc.201700756

97. Shamim, Anwar; Souza, Frederico B.; Trossini, Gustavo H. G.; Gatti, Fernando M.; Stefani, Helio A. Mol. Div. 2015, 19, 423-434. https://doi.org/10.1007/s11030-014-9564-0

98. Chahdoura, F.; Pradel, C.; Gomez, M. Chem. Cat. Chem. 2014, 6, 2929-2936. https://doi.org/10.1002/cctc.201402214

99. Elamari, H.; Slimi, R.; Chabot, G. G.; Quentin, L.; Scherman, D.; Girard, C. Eur. J. Med. Chem. 2013, 60, 360-364. https://doi.org/10.1016/j.ejmech.2012.12.025

100. Zhang, H. Tanimoto, T. Morimoto, Y. Nishiyama, K. Kakiuchi, Tetrahedron 2014, 70, 9828-9835. https://doi.org/10.1016/i.tet.2014.10.076

101. Zhang, X.; Li, H.; You, L.; Tang, Y.; Hsung, R. P. Adv. Syn. Cat. 2006, 348, 2437-2442. https://doi.org/10.1002/adsc.200600404

102. Ruan, Y.-B.; Yu, Y.; Li, C.; Bogliotti, N.; Tang, J.; Xie, J. Tetrahedron 2013, 69, 4603-4608. https://doi.org/10.1016/j.tet.2013.04.024

103. Katritzky, A. R.; Zhang, Y.; Singh, S. K.; Steel, P. J. Arkivoc 2003, 47-64.

104. Abu-Orabi, S.; Atfah, A.; Jibril, I.; Marii, F.; Ali, A. A. Gazz. Chim. Ital. 1991, 121, 397-400.

105. Hemamalini, A.; Das, T. M. RSC Advances 2014, 4, 34189-34198. https://doi.org/10.1039/C4RA04084H

106. Oleiwi, Z. K.; Mohammed, I. F.; Thamer, A. N. Pharma Chem. 2016, 8, 34-37.

107. Ghosh, K.; Panja, A.; Panja, S. New J. Chem. 2016, 40, 3476-3483. https://doi.org/10.1039/C5NJ02771C

108. Mohammed, A. I.; Abboud, Z. H.; Alghanimi, A. H. O. Tetrahedron Lett. 2012, 53, 5081-5083. https://doi.org/10.1016/j.tetlet.2012.07.014

109. Oladeinde, O. A.; Hong, S. Y.; Holland, R. J.; Maciag, A. E.; Keefer, L. K.; Saavedra, J. E.; Nandurdikar, R. S. Org. Lett. 2010, 12, 4256-4259.

https://doi.org/10.1021/ol101645k

110. Mishra, K. B.; Mishra, B. B.; Tiwari, V. K. Carbohydr. Res. 2014, 399, 2-7. https://doi.org/10.1016/i.carres.2014.09.001

111. Padmaja, A.; Pedamalakondaiah, D.; Sravya, G.; Reddy, G. M.; Kumar, M. V. J.; Rao, C. A. Med. Chem. Res. 2015, 24, 2011-2020. 
112. Sayed, A. R. Tetrahedron 2013, 69, 5293-5298.

https://doi.org/10.1016/j.tet.2013.04.137

113. Li, S. H.; Pang, S. P.; Li, X. T.; Yu, Y. Z.; Zhao, X. Q. Chin. Chem. Lett. 2007, 18, 1176-1178. https://doi.org/10.1016/j.cclet.2007.08.018

114. Fang, B.; Zhou, C.-H.; Rao, X.-C. Eur. J. Med. Chem. 2010, 45, 4388-4398. https://doi.org/10.1016/i.ejmech.2010.06.012

115. Shaker, R. M.; Mahmoud, A. F.; Abdel-Latif, F. F. Phosphorus, Sulfur Silicon Rel. Elem. 2005, 180, $397-406$. https://doi.org/10.1080/104265090509199

116. Shivarama H. B.; Narayana P. K.; Sooryanarayana R. B.; Shivananda, M. K. Eur. J. Med. Chem. 2002, 37, 511-517.

https://doi.org/10.1016/S0223-5234(02)01358-2

\section{Authors' Biographies}

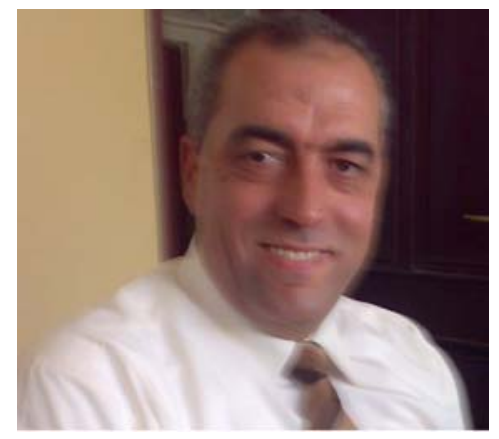

Kamal M. Dawood graduated from Cairo University, Egypt in 1987 then carried out his MSc and PhD studies under the supervision of Professor Ahmad Farag, Cairo University and received his PhD in 1995. In 1997 he was awarded the UNESCO Fellowship for one year and in 1999 he was awarded the JSPS (Japan Society for Promotion of Science) Fellowship for two years and in both fellowships, he worked with Professor Toshio Fuchigami at Tokyo Institute of Technology (TIT) in the field of 'Anodic Selective Fluorination of Heterocyclic Compounds'. In addition, he was awarded the Alexander von Humboldt (AvH) Fellowship at Hanover University in 2004-2005 with Prof. Andreas Kirschning (in the area of polymer supported palladium catalyzed cross coupling reactions) and in the summer of 2007, 2008 and 2012 AvH Fellowship with Prof. Peter Metz at TU-Dresden (in the field of Metathesis Reactions in Domino Processes). In 2002 he promoted to Associate Professor and in May 2007 he was appointed as Professor of Organic Chemistry, Faculty of Science, Cairo University. In 2002 he received the Cairo University Award in Chemistry and in 2007 he received the StateAward in Chemistry. He worked as Professor of Organic Chemistry at Chemistry Department, Kuwait University from Sept. 2013 till Aug 2017. In 2012 he received the Cairo University Award for Academic Excellence. He published more than 120 scientific papers and reviews in distinguished international journals with about 2050 citations of his work ( $h$-index 24). 


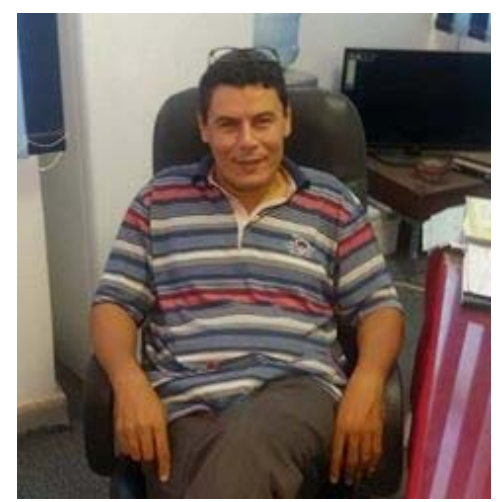

Mohamed A. Raslan was born in Sohag, Egypt (1964) and received his B.Sc. Degree (Honor) in Chemistry from Assiut University (1986) followed by M.Sc. and Ph.D. from Assiut University 1991 and 1994, respectively under the supervision of Prof. Dr. M. H. Elnagdi (Faculty of science, Cairo University, Egypt). He was appointed as a demonstrator of Chemistry at Faculty of science, Aswan University in 1988. He was appointed as a lecturer of organic chemistry in 1994, Associate Prof. of Organic Chemistry, 2008, and Professor of Organic Chemistry 2015. His major interests are Green methodologies in organic synthesis including Microwave irradiation, solar thermochemical reactions, solventless organic synthesis, organic synthesis in water, utility of green catalysts in organic synthesis and Heterogeneous catalysis. Currently, he is the Vice-Dean for Education and Student Affairs at the Faculty of Science, Aswan University, Egypt.

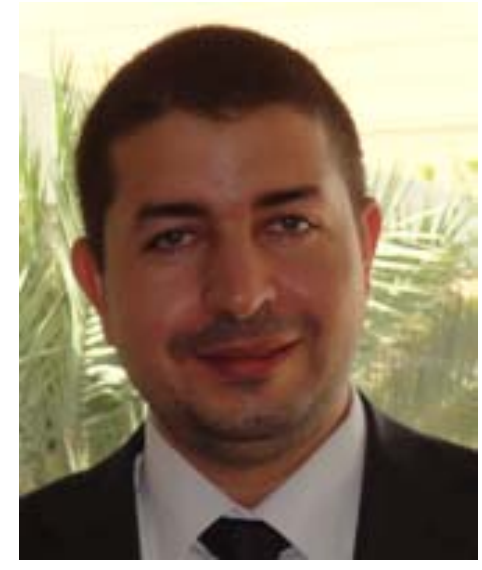

Bakr F. Abdel-Wahab was born in 1978 in Mansoura, Egypt. He is associate professor of organic chemistry at National Research Centre, Giza, Egypt. He has got his B.Sc. in 1999 from Chemistry Department, Faculty of Science, Mansoura University, Egypt. He received his M.Sc. in 2003 from the same university. He has awarded his Ph.D. degree in 2007 from Ain-Shams University, Cairo, Egypt. He worked as an assistant professor at Department of Chemistry, Faculty of Science, King Abdul-Aziz University, Saudi Arabia during the period 20092011. Currently, he is working at Faculty of Science, Shaqra University, Al-dawadami, Saudi Arabia from Sept. 2012 till now. In 2012 he received the State-Award in Chemistry, Egypt, and in 2013 he received the award of Arab chemists Union for youth. His current research interests cover the development and mechanistic aspects of organic reactions and their applications in medicinal and industrial chemistry. 